\title{
AVALIAÇÃO QUÍMICA, BIOLÓGICA E NUTRICIONAL DA FARINHA DE TREMOÇO BRANCO DOCE (Lupinus albus VAR. MuLTOLUPA). EMPREGO NA ELABORAÇÃO DE IOGURTE
}

\author{
MARIA SEBASTIANA SILVA
}

Dissertação apresentada à Escola Superior de Agricultura "Luiz de Queiroz", da Universidade de São Paulo, para obtenção do título de mestre em Ciências, área de concentração: Ciência $\theta$ Tecnologia de Alimentos.

PIRACICABA

Estado de São Paulo - Brasil

Novembro - 1991 


\begin{abstract}
AVALI AÇZ̃o QUI MICA, BIOLOGI CA E NUTRICIONAL DA FARINHA DE TREMOÇO BRANCO DOCE (LupinUs albus var. Multolupa) EMPREGO NA ELABORAÇT̃O DE IOGURTE
\end{abstract}

\title{
MARIA SEBASTIANA SILVA
}

Aprovada em: 17.12 .1991

Comissão Julgadora

$\begin{array}{ll}\text { Prof. Drå. Jocelen Mastodi Salgado } & \text { ESALQ/USP } \\ \text { Prof. Dr. Antonio Joaquim de Oliveira } & \text { ESALQ/USP } \\ \text { Prof. Dr. Luiz Eduardo Gutierrez } & \text { ESALQ/USP }\end{array}$

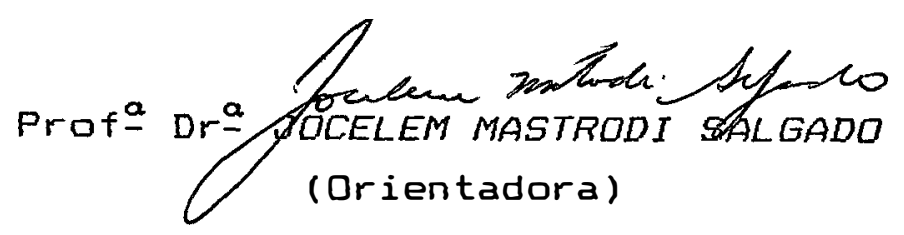


i i i

Aos meus pais Hiram e Mercedes, que mesmo distantes me apoiaram na busca de meus ideais, que me ensinaram a lutar e acreditar que por mais árdua que seja a luta sempre haverá uma recompensa. 


\title{
AGRADECIMENTOS
}

\begin{abstract}
E Professora Drå JOCELEM MAstrod I SALGADO, pela orientaçăo, amizade, dediçăo, confiança e apoio que muito contribusram na realização deste trabalio e no enriquecimento profissional;
\end{abstract}

Ao Professor Dr. Antonio Joaquim de Oliveira, do Departamento de Tecmologia de Alimentos, da ESALQ/USP, pela colaboração prestada;

A Professora DräMaria Cristina S. Nogueira do Departamento de Matematica e Estatistica, ESALQ/USP, pela assessoria na análise estatistica dos dados;

A Cooperativa Regional Triticola Serrano de IjuiSC, pelo fornecimento dos grăos de tremoço utilizado neste trabalio;

Á Professora Solange C. Canatiatti - Brazaca, pela amizade e auxilio prestado;

A Técnica de laboratório Maria de Lourdes Perin Storer, da ESALQ/USP pela amizade, apoio e valiosa colaboraçăo no decorrer do trabalho experimental.

Á Raquel Iracema da Silva, secretária do Setor de Nutrição Humana e Alimentos, da ESALQ/USP, pela amizade, apoio e serviços datilográficos prestados; 
As Bibliotecárias Beatriz Helena Giongo e Kátia Maria Andrade Ferraz, pela orientaçăo das normas na elaboraçăo das bibliografias;

Ao Estagiário do Setor de Nutriçăo Humana Paulo Gustavo Galane, pelo auxilio no decorrer do trabalho experimental;

A Professora Gersilei Antónia Salado do Departamento de Nutrição e Farmácia da Universidade do Sagrado Coraçăo/Bauru, pela amizade e colaboração;

Ás Colegas Andréa C. Dario e Márcia de L. de Francischi, pela amizade e dedicaçăo;

A Todas as pessoas que direta ou indiretamente colaboraram para a realização deste trabalho. 


\section{SUMARIO}

Página

LISTA DE FIGURAS ........................ ix

LISTA DE TABELAS ........................ $\quad x i$

RESUMO ............................. $x i i$

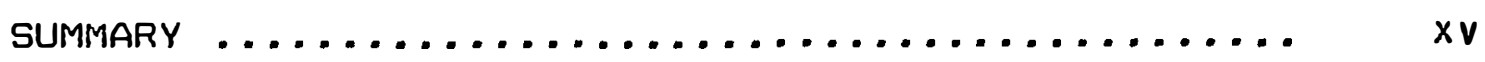

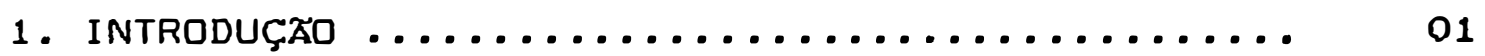

2. REVISÃo de literatura .................... 04

2.1. Tremoço - histórico ................. 04

2.2. Classificaçăo botånica das principais espé-

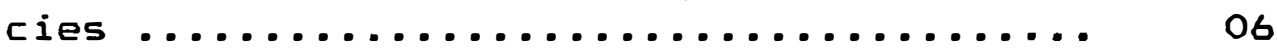

2.3. Características agronómicas do tremoço ..... 06

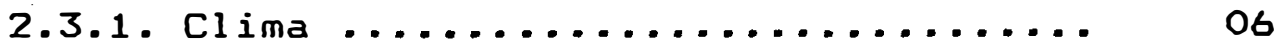

2.3 .2 . Solo ..................... 07

2.3.3. Preparo do solo e semeadura ....... 08

2.3.4. Epoca de semeadura e rendimento .... 09

2.4. Composiçăo do tremoço ................. 09

2.4.1. Minerais ................... 09

2.4.2. Lipidios ..................... 11

2.4.3. Carboidratos .................. 12

2.4.4. Proteinas .................... 13

2.4.5. Aminoácidos ..................... 14

2.5. Fatores antinutricionais presentes no tremoço ......................... 15

2.6. Tratamento nos grãos de leguminosas para obtenção de farinhas ................. 18

2.7. Complementaçăo da farinha de tremoço para elaboração de produtos alimentícios ........ 
Página

3. MAteriais e metodos .................... 28

3.1. Matéria prima .................... 28

3.2. Elaboração de farinhas ............... 28

3.2.1. Farinhas de tremoço ............. 28

3.2.1.1. Maceração em água contendo bicarbonato de sódio ...... 29

3.2.1.2. Tostagem dos grãos ....... 29

3.2.1.3. Maceração em água destilada acidificada com $\mathrm{HCl}$ \& $0,12 \mathrm{~N} \quad 30$

3.2.1.4. Maceração em água contendo metabissulfito de sódio ... 31

3.2.2. Farinha de arroz .............. 31

3.2.3. Farinha de semente de abóbora ...... 32

3.2.4. Farinha de milho opaco-2 ........ 33

3.2.5. Farinha de ervilha ............ 33

3.2.6. Farinha de feijăo caupi ......... 33

3.3. Preparo da mistura proteica ............ 34

3.4. Preparo das dietas experimentais ........ 35

3.5. Análise bromatologica .............. 37

3.6. Ensaio biológico ................... 38

3.7. Preparo do extrato l1quido "leite de tremoco" ................................ 40

3.8. Elaboração do produto fermentado com bactérias láticas - "iogurte de tremoço" ..... 41

3.9. Análise de minerais ................ 42

3.10. Análise sensorial .................. 42

3.11. Análise estatŕstica ................. 44

4. Resultados E discussão ..................... 45

4.1. Farinhas ......................... 45

4.2. Análise bromatológica ................ . 46

4.2.1. Farinhas ................... 46

4.2.2. Dietas experimentais ............ 51 


\section{$v \boldsymbol{i} \mathbf{i}$}

Página

4.3. Ensaio biologico .................... 54

4.3.1. Primeiro ensaio biologico ......... 54

4.3.2. Segundo ensaio biológico .......... 62

4.4. Análises do extrato liquido ("leite") e produto fermentato ("iogurte") ........... 71

4.4.1. Análise bromatologica ........... 72

4.4.2. Análise de minerais ............. 74

4.4.3. Análise sensorial ............... 76

5. CONCLUSoES .............................. 79

REFERENCIAS BIBLIOGRAFICAS ................ 81

APENDICE $\ldots \ldots \ldots \ldots \ldots \ldots \ldots \ldots \ldots \ldots \ldots \ldots \ldots \ldots \ldots \ldots \ldots$ 


\section{LISTA DE FIGURAS}

FIGURA N•

Página

01 Ganho de Peso dos animais, referente a cada dieta, durante o 1 • ensaio biológiс $\ldots \ldots \ldots \ldots \ldots \ldots \ldots \ldots \ldots \ldots \ldots \ldots \ldots \ldots . \ldots \ldots \ldots$

02 Valores do Coeficiente de Eficácia (CEA), referente a cada dieta, durante o $1^{\circ}$ ensaio biologico ...................

03 Valores da Taxa de Eficiencia Proteica (PER), referente a cada dieta, durante 0 1. ensaio biológico ................

04 Valores da Utilização Liquida da Protelna (NPU), referente a cada dieta, durante 0 1. ensaio biológico ...............

05 Valores da Digestibilidade (D), referente a cada dieta, durante o 1 o ensaio biolo-

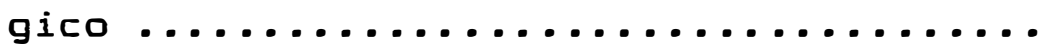

O6 Valores do Valor Biológico (VB), referente a cada dieta, durante o $1^{\circ}$ ensaio bio-

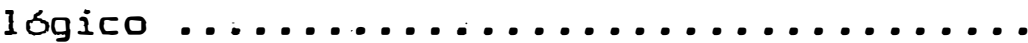

07 Ganho de Peso dos animais, referente a cada dieta, durante o $2 \circ$ ensaio biológico

08 Valores do Coeficiente de Eficácia Alimentar (CEA), referente a cada dieta, durante o $2 \circ$ ensaio biológico ........... 
FIGURA No

Página

09 Valores da Taxa de Eficiéncia Proteica (PER), referente a cada dieta, durante 0 2. ensaio biologico ................

10 Valores da Utilização Liquida da Protelna (PER), referente a cada dieta, durante o 2. ensaio biológico ................

11 Valores da Digestibilidade (D), referente a cada dieta, durante 02 ensaio biologico ....................... 68

12 Valores do Valor Biológico (VB), referente a cada dieta, durante o 2 e ensaio bio-

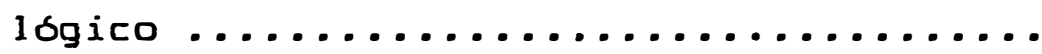

13 Classificação dos "iogurte de tremoço" e iogurte natural (sem sabor e adicionados de sabores) quanto à acidez, sabor, aro-

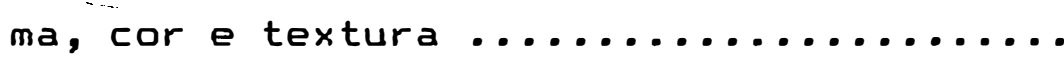

14 Classificação dos "iogurte de tremoço" (sem sabor e adicionados de sabores), quanto ao grau de preferéncia ......... 


\section{LISTA DE TABELAS}

TABELA No

Página

01 Composição bromatológica das farinhas de tremoço obtidas por diferentes tratamen-

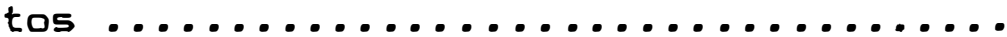

02 Composição bromatológica das farinhas utilizadas para complementaçăo da fari-

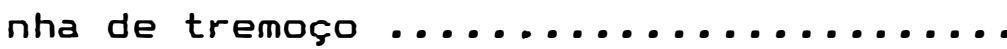

03 Composição bromatológica das dietas experimentais elaboradas com farinhas de tremoço submetidas à diversos tratamen-

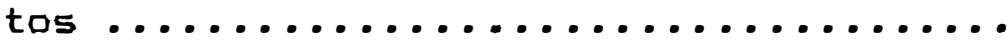

04 Composição bromatológica das dietas exprimentais elaboradas com as farinhas de tremoço complementadas ..............

05 Composição bromatológica do "leite" e "iogurte" de tremoço ..............

O6 Conteúdo de lactose no "iogurte de tremoço", iogurte natural e "leite de tremoço", adicionado de $10 \%$ de leite em pó desnatado e $10 \%$ de iogurte natural ....

07 Conteúdo de minerais do "leite de tremoço" e "iogurte de tremoço" .......... 
AVALIAÇão QUIMICA, BIOLGGICA E NUTRICIONAL DA FARINHA DE TREMOÇO BRANCO DOCE (Lupinus albus var. Multolupa). EMPREGO NA ELABORAÇãO DE IOGURTE

Autora: Maria Sebastiana Silva Orientadora: Prof : Dr : Jocelem Mastrodi Salgado

RESUMO

As farinhas obtidas de grăos de tremoço crus, grãos de tremoço submetidos a diferentes tratamentos $e$ as farinhas complementadas foram avaliadas quanto às caracteristicas bromatológicas e nutricional. Os tratamentos empregados aos grãos de tremoço foram: torrefação (90॰C) por 10, 20, 30 e 40 minutos; meceraçăes com agua destilada, acidificada a $\mathrm{pH} 2,0,4,0$ e 6,0; com $0,5 \%$ de bicarbonato de sódio e com 2\% de metabissulfito de sódio. Us teores de proteinas foram de $35,7 \%$ no tremoço cru, 46,3 a $50,9 \%$ nos obtidos da maceração em água destilada acidificada com HCl $1 \%, 39,9$ a $43,5 \%$ nos torrados, $49,8 \%$ quando tratado com bicarbonato de sódio e de $56,3 \%$ no tratado com metabissulfito de sódio.

Os valores do PER (Taxa de Eficiência Proteica) encontrados na avaliação da qualidade das proteinas das farinhas, foi de 0,90 para a farinha de tremoço cru, oscilando, porém de 0,11 a 0,90 para os demais tratamentos. 
A farinha de tremoço obtida da maceração em água destilada a pH 2,0 foi a escolhida para a elaboração das misturas proteicas uma vez que apresentou os maiores valores para a Utilização Liquida de Protelna $(42,00 \%)$ e Valor Biológico $(56,06 \%)$. Outra farinha selecionada para ser utilizada na elaboração de misturas proteicas foi a obtida do tratamento com metabissulfito de sódio, devido a ausência de sabor amargo.

A complementação aminoacidica da farinha de tremoço foi feita com o emprego de farinhas de trigo, arroz, semente de abóbora, ervilha, milho opaco-2 e feijão caupi. As misturas das farinhas de trigo $(70 \%)+\operatorname{tremoço~}(25 \%)+$ feijăo caupi (5\%), trigo $(50 \%)$ + tremoço $(35 \%)$ + feijăo caupi $(15 \%)$ e tremoço $(70 \%)$ + semente de abóbora (30\%) foram as que apresentaram maior qualidade nutricional, com valores para O PER de $1,80,2,04$ e 2,17, respectivamente.

a produto alimenticio produzido foi o "iogurte de tremoço" obtido da fermentação do "leite de tremoço" extraldo dos grãos tratados com metabissulfito de sódio. a produto apresentou caracteristicas organolépticas desejáveis e boa aceitabilidade. Os dados coletados sobre a preferéncia demonstraram que o "iogurte de tremoço" com sabor morango foi o mais apreciado entre os demais.

Os resultados obtidos em todas as fases do trabalho mostraram que a farinha de tremoço apresentou baixa qualidade nutricional, porém a sua complementação com ce- 
reais e oleaginosas promoveu um aumento do seu valor, sendo possivel sua utilização em produtos alimenticios. Os estudos sobre a qualidade nutricional do "leite" e "iogurte" de tremoço devem ser pesquisados, bem como a elaboração de outros produtos alimenticios. 
CHEMICAL, BIOLOGICAL AND NUTRITIONAL EVALUATION OF SWEET WHITE LUPIN FLOUR (Lupinus albus var. Multolupa). USE IN YOGURT ELABORATION

Author: Maria Sebastiana Silva Adviser: Jocelem Mastrodi Salgado

\section{SUMMARY}

Flour from raw lupin grain and from lupin grains submitted to different treatments and complemented flour were evaluated concerning chemical and nutritional characteristics. The lupin grains were submitted to the following treatments: roasting at $90 \circ \mathrm{C}$ for $10,20,30$ and 40 minutes; soaking in: acidified distilled water ( $\mathrm{pH} 2.0,4.0$ and 6.0); sodium bicarbonate and with $2 \%$ sodium metabisulfite. The protein content was $35.7 \%$ in raw lupin, 46.3 to $50.9 \%$ when soaked in acidified destilled water, 39.9 to $43.5 \%$ in roasted grains, $49.8 \%$ when soaked water plus sodium bicarbonate and $56.3 \%$ in water plus sodium metabisulfite treated grains.

The PER (Protein Efficiency Ratio) value obtained from the evaluation of the flour protein quality was 0.90 for raw lupin flour varying however from 0.11 to 0.35 for the other. The lupin flour obtained from maceration in distilled water at $\mathrm{pH} 2.0$ was selected to elaboration of protein mixtures since it presented the 
highest values for the Net Protein Utilization (42\%) and Biological Value (56.06\%). Also selected for the elaboration of the protein mixtures was the flour sodium metabisulfite treatment due to the lack of bitter flavor. The aminoacid complementation of the lupin flour was made with wheat, rice, pumpkin seed, peas, opaque maize-2 and cowpea bean flours. The wheat (70\%) + lupin $(25 \%)+$ cowpea bean $(5 \%)$, wheat $(50 \%)+$ lupin $(35 \%)+$ cowpea bean (15\%) and lupin (70\%) + pumpkin seed (30\%) flours mixtures presented the highest nutritional qualities with PER values of $1.80,1.04$ and 2.17 , respectively.

"Lupin Vogurt" was prepared from fermentation of "lupin milk" extracted from grains treated in sodium metabisulfite. The product presented desirable organoleptic characteristics and good acceptability better flavour. Data collected on preference showed that the strawberry flavour "lupin yogurt" was the most appreciated among all.

The results obtained in all phases of the work showed that the lupin flour presented low nutritional quality, but the complementation with cereals and oleaginous elements increased its nutritional value, allowing it to be used as human feed. Studies about raw and ferment lupin "milk" (yogurt) must be researched as well as the elaboration of the others human feed. 


\section{INTRODUÇĀO}

o tremoço é uma leguminosa pertencente ao gênero Lupinus, conhecida a 2.000 anos pelos povos romanos. As primeiras informaçỡes sobre o cultivo de tremoço com alto teor de alcalóides (amargo), no Brasil, datam do infcio do século. Em 1980, foram cultivados no sul do pals mais de 100.000 hectares para adubação verde (CATAPAN et alii, $1988)$.

0 tremoço branco é, das espécies em cultivo, a mais antiga. Desde os tempos dos impérios romanos e grego, essa espécie é cultivada graças a sua rusticidade e adaptação em terras com baixa fertilidade (UFER, 1956; SCHERER, 1962).

0 tremoço contém elevado conteúdo de proteina bruta, ou seja, de até 42\% no grão, o que viabiliza a possibilidade de sua utilização na alimentação humana (SANTOS et ali 1984 ).

A utilização do tremoço amargo na alimentação humana tem sido restrita, devido a presença de alcalóides nos grãos dessa espécie. Entretānto, seleçơes genéticas tem 
levado ao desenvolvimento de variedades de tremoço doce, com baixo teor de alcalóides $(0,09 \%)$ e alta produçăo de grăos (1-25 t/ha) o que constitui uma excelente fonte de protelna para a alimentaçăo humana, despertando interesse internacional como um potencial na agricultura (CAMPOS \& EL-DASH, 1978).

Os grăos de tremoço de algumas variedades tém apreciáveis teores de óleo, o que contribui para o aumento de seu valor energético. 0 teor de fibra bruta é relativamente alto, principalmente nas espécies de L. albus.

A qualidade da proteína para a alimentaçăo humana depende de sua digestibilidade e dos teores de aminoácidos. Os grãos de tremoços apresentam baixos teores de aminoácidos sulfurados, tendo como primeiro limitante a metionina, porém, săo boas fontes do aminoácido lisina. Portanto, a elaboração de farinhas com grăos de tremoço e sua complementação com outras fontes protéicas deficientes em lisina e ricas em aminoácidos sulfurados, principalmente metionina, para a obtenção de misturas proteicas de alto valor nutricional seria de grande importáncia nos estudos sobre fontes proteicas năo convencionais.

Diante das vantagens que os grăos de tremoço apresentam, como fonte alternativa na elaboraçăo de produtos para alimentação humana; é que se propós desenvolver esta pesquisa tendo como objetivo: preparar farinha de tremoço e complementá-la com farinha de arroz, milho opaco-2, ervilha, 
trigo, semente de abobbora e feijăo-caupi; verificar a qualidade nutricional através das análises bromatológica e biológica; elaborar um produto fermentado com bactérias láticas, semelhante ao iogurte natural e verificar a aceitabilidade desse produto fermentado. 


\title{
2. REVISÃo DE LITERATURA
}

\subsection{Tremoço - histórico}

\begin{abstract}
0 tremoço, conhecido cientificamente como Lupinus vem sendo explorado pelo homem desde épocas antes de Cristo. No inćio da era cristã o tremoço já fazia parte da agricultura romana e grega, embora fosse conhecido no Egito e Mesopotámia antes deste periodo. 0 médico grego Hipócrates e. Theophratus, 400 a.C., mencionaram a utilização do tremoço na alimentação humana. Vários escritos romanos, também nesta era, relataram sobre o cultivo do tremoço em solos pobres e seu uso como alimento (GROSS \& VON BAER, 1977; AGUILERA \& TRIER, 1978).

Algumas espécies como Lupinus albus e o Lupinus mutabilis, têm sido cultivadas para a produção de grãos há mais de três mil anos na região do mediterråneo e nas altas colinas da América do Sul, respectivamente.
\end{abstract}

A expansão inicial. do tremoço do velho mundo, foi devida principalmente, a sua habilidade em se adaptar 
bem às mais diferentes condiçơes edafoclimaticas (SCHERER, 1982).

As espécies nativas de tremoço são amargas devido ao seu alto teor de alcalóides, o que restringe a sua utilização na alimentação animal e humana. Várias pesquisas foram realizadas na Alemanha e Rússia (1928/29), com a finalidade de obtenção de variedades doces de tremoço, isto é, isentas de subståncias tóxicas. Após examinar milhares de plantas de tremoço, selecionou-se algumas espécies, variedades doces; as quais originaram as cultivadas atualmente. Os tremoços doces contém, no máximo, 0,025\% de alcalóides (FLOSS, 1980).

A Polónia e a Hungria foram os passes que mais incentivaram a produção de tremoço para grãos, principalmente para a alimentação humana, no periodo após a segunda Guerra Mundial .

Na América do Sul, o Chile foi o pals que possuiu a maior área cultivada com tremoço, principalmente de Lupinus albus, para produção de grãos. No Brasil, o tremoço foi cultivado essencialmente para adubação verde, destacando-se as espécies de origem mediterrånea (Lupinus albus, Lupinus Iuteus e Lupinus angustifoliusl, que foram os que melhores se adaptaram as condiçơes edafoclimáticas da região do sul do pais. Estas espécies apresentaram um alto potencial de cultivo no Estado de. Santa Catarina, principalmente em sistema de rotação de culturas, melhorando as 
caracteristicas físicas e quimicas do solo (SCHERER, 1982).

2. 2. Cilassificação botánica das principais espécies de tremogo

o tremoço é uma planta herbacea anual da famlila das leguminosas, com um grande número de espécies. Dentre as espécies mais difundidas no mundo e que podem ser consideradas de interesse para adubação verde e produção de grăos, destacam-se: Lupinus albus (tremoço branco), Lupinus luteus (tremoço amarelo); Lupinus angustifolius (tremoço azul) e Lupinus mutabilis (tremoço peruano) (FLOSS, 1980; SCHERER, 1982).

\section{3. Caracteristicas agronômicas do tremoço}

\subsubsection{Clima}

o cultivo do tremoço e simples e pode ser
comparado ao do feijão. Em geral, seu cultivo se dá em
regiás de climas frios e subtropicais, não tolera estaçăes
muito quentes e úmidas e as exigencias térmicas variam com
as diferentes espécies. 0 Lupinus angustifolius e o mais 
adaptado as condiçôs de clima frio e, durante o estágio vegetativo, tolera esporadicamente temperaturas de ate $-6{ }^{\circ} \mathrm{C}$. o Lupinus luteus tolera geadas, porém é mais sensivel ao frio, no periodo vegetativo, do que o tremoço azul. Já o Lupinus albus vem sendo cultivado numa grande amplitude de condiçơes climáticas, está mais adaptado a climas subtropicais e possui menor tolerancia a baixas temperaturas que o azUl (SCHERER, 1982; UFER, 1956).

\section{3.2. Solo}

o tremoço amarelo vegeta perfeitamente em solos arenosos e ácidos, enquanto o branco e o azul adaptamse melhor em solos mais pesados e argilosos. Fundamentalmente são cultivados em solos de pouca fertilidade, sobretudo, em solos ácidos, inadequados para outras leguminosas forrageiras. E uma cultura que se adapta bem ao solo com baixa fertilidade, pois tem alta capacidade de mobilizar e extrair nutrientes com seu sistema radicular abundante e profundo. Assim, tem a capacidade de enriquecer o solo com nitrogênio e transformar os fosfatos de dificil solução em combinaçס̋es mais facilmente solúveis (FLOSS, 1980; . SCHERER, 1982; UFER, 1956).

Quando o cultivo se destina a produção de grãos, o tremoço requer um adequado suprimento de nutrientes, através da adubação mineral. Normalmente é requerido 
uma adubação com fosfatos $\left(P_{2} O_{5}\right)$, mas também são usadas complementaçơses com potasssio, enxofre e alguns micronutrientes como molibdenio, cobalto, zinco, manganess e cobre, em solos deficientes destes nutrientes (SCHERER, 1982).

\subsubsection{Preparo de solo e semeadura}

o preparo do solo é, geralmente, feito com uma lavração, e uma ou duas gradagens, com o objetivo de oferecer boas condiçరes para semeadura para germinação uniforme das sementes e para o controle da competição de ervas daninhas, além de favorecer a infiltração e o armazenamento de água no solo.

Para a semeadura do tremoço pode ser usada a mesma semeadeira que é empregada para distribuir as sementes de soja; basta que seja feita uma regulagem para semear o número desejado de sementes a uma profundidade de 3 a 5 cm (SCHERER, 1982).

Segundo FLOSS (1980), recomenda-se usar 20 sementes aptas por metro linear, sendo o espaçamento de 0,80m entre linhas, quando o objetivo for a produção de sementes e $0,40 m$ entre linhas para adubação verde. SCHERER (1982) recomendou para o Estado do Paraná, um espaçamento de 30 a $35 \mathrm{~cm}$ e 70 e $80 \mathrm{~cm}$ entre linhas e 8 a 10 sementes/m para a semeadura do tremoço branco para a adubação verde e produção de sementes, respectivamente. 


\subsection{Epoca da semeadura e rendimento}

Para o cultivo de tremoço com o objetivo de adubação verde, prefere-se que a semeadura seja feita em abril e maio. Para colheita de sementes, o plantio deverá ser feito em junto e julho (FLOSS, 1980).

0 rendimento de massa verde e dos grãos de tremoço branco doce, de acordo com UFER (1956), poderá chegar a 30-40 toneladas e 1400-2000 quilos por hectare, respectivamente. BENASSI (1988), estudou os efeitos da época de semeadura, espaçamentos e momentos de corte sobre o desenvolvimento, produção: massa verde, matéria seca e sementes de Lupinus albus L., no municipio de Bandeirantes (Paraná); e verificou entre outros que a produção média de sementes foi $2691 \mathrm{~kg} / \mathrm{ha}$ quando a semeadura ocorreu em março e visando um espaçamento de $0,20 m$ entre linhas, em contraste com uma produção de $473 \mathrm{~kg} / \mathrm{ha}$, com semeadura em junho e com espaçamentos de $0,40 \mathrm{~m}$.

\section{4. Composição do tremoço}

\section{4.1. Minerais}

A composição mineral de várias espécies de tremoço foi estudada por diversos autores, os quais enfatizaram o teor de manganês nas sementes, e em produtos alimenticios elaborados com as mesmas (HUNG et alii, 1987; HUNG 
et alii, 1988). Estudos sobre o teor de manganés em Lupinus albus, cultivado na Austrália, mostraram que o mesmo apresenta valores altos $(3390 \mathrm{mg} / \mathrm{kg})$ do referido mineral . Entretanto, foram encontrados valores de $164 \mathrm{mg} / \mathrm{kg}$, sugereindo que os teores desse mineral, encontrados nas sementes de tremoço foram causados pela habilidade das ralzes da planta em absorver o manganes do solo (HILL, 1977).

HUNG et alii (1987), compararam o conteúdo de manganes de 33 amostras de sementes de duas espécies de tremoço (Lupinus albus e Lupinus angustifolius). Ds teores médios de manganés nas sementes de Lupinus albus e Lupinus angustifolius foram 1316 e $61 \mathrm{mg} / \mathrm{kg}$, respectivamente. Os autores também analisaram o conteưdo do referido mineral na farinha, pó liofilizado e - isolado proteico elaborado de algumas amostras das duas espécies de tremoço. Concluiram que os altos niveis de manganes encontrados nas sementes de Lupinus albus, permaneceram na farinha è pó liofilizado obtidos a partir das mesmas e sugeriram que as variedades que contém baixo teor de manganés podem ser utilizadas para produção de alimentos destinados ao consumo humano enquanto que as que contém niveis altos, o uso deve ser restrito.

0 manganes é um elemento essencial requerido para a crescimento e reprodução de mamiferos. A ingestão diária recomendada para adultos é de 2,5 a $3,0 \mathrm{mg}$ e a maioria das dietas normais contêm. niveis essenciais desse mineral (HUNG, 1987). Embora o manganes seja um elemento 
essencial, ele pode causar problemas de toxidez, quando ingerido em quantidade acima do recomendado.

Em relação ao consumo humano, foi relatado que a ingestão de água contendo niveis elevados de manganess pode ocasionar perda de apetite, perda de memória ou então distúrbios mentais (WHO, 1971).

A composição mineral das sementes, casca e endosperma de duas espécies de tremoço ( $L$. albus e $L$. angustifolius), foram estudadas por HUNG et alii (1988). Os resultados encontrados pelos autores, indicaram que o cálcio, alumínio e boro, estavam presentes em concentração mais alta nas cascas, enquanto os outros minerais estavam em maior quantidade no endosperma.

\subsubsection{Lipidios}

A quantidade de lipidios (extrato etéreo) presente na maioria das espécies de tremoço é menor que $7 \%$, porém, as espécies $L$. albus e L. mutabilis contém, em média 17 e $23 \%$ de óleo, respectivamente, podendo ser utilizada na indústria de óleo (HILL, 1977). A fração lipidica das sementes de tremoço compơem-se, principalmente, de ácidos graxos insaturados (GROSS \& VAN BAER, 1977; HILL, 1977; AGUILERA \& TRIER, 1978; MÚzQUIz et alii, 1989). 0 ácido oleico está presente em grande quantidade (acima de 50\%) no L. albus e L. mutabilis, enquanto que o ácido linoleico predomina no L. Iuteus e L. angustifolius. 
o ácido erúcico foi encontrado em niveis significantes nos L. albus (MUZQUIZ et alii, 1989).

\section{4. 3. Carboidratos}

As sementes da maioria das espécies de tremoço são ricas em fibras, devido, principalmente, a quantidade de casca contidas nos grãos.

Segundo SGARBIERI \& GALEAZZI (1978), as cascas das sementes de L. albus representam $17 \%$ do peso seco das mesmas e são responsáveis por $13 \%$ da fibra crua. Os autores ainda afirmaram que as cascas devem ser removidas, quando as sementes de tremoço forem destinadas a produção de alimentos, para consumo humano, melhorando assim a digestibilidade do produto.

0 tremoço contém baixo teor de amido e grande quantidade de polissacarideos estruturais da parece celular. GROSS \& VON BAER (1977), encontraram no L. angustifolius cV. Huancayo 6 e L. albus cV. Astra a quantidade de 2,8 e 8,0\% de amido respectivamente. CERNING \& FILIATRE (1976), em um estudo comparativo da composição de carboidratos presente nas sementes de tremoço, feijăo cavalo e ervilha, relataram que a composição média de amido para o tremoço e feijão cavalo foi de 0,1 e $41 \%$, respectivamente; na ervilha ocorre uma variação de 33-48\%, dependendo da variedade. TRUGO et alii (1988), avaliaram o conteúdo de oligossacarideos em seis especies de tremoço, e observaram que em todas as 
espécies, a estaquiose foi encontrada em maior quantidade. Os autores ainda relataram que a conteúdo de oligossacarídeos e distribuição nas sementes de tremoços, parecem ser mais influenciados pelo ambiente do que pelo genótipo, uma vez que o período de vegetação curto promove um aumento significante no conteúdo de verbascose e diminuição no de sacarose.

\section{4. 4. Protel nas}

Considerando-se que o conteúdo de nitrogénio não proteico dos grãos de tremoço, como nas demais leguminosas é alto, GROSS \& VON BAER (1977) propuseram a multiplicação do conteúdo de nitrogénio por 5,7 uma vez que o fator 6,25 supervalorizaria o teor de protelna do mesmo.

SGARBIERI \& GALEAZZI (1978) verificaram que o teor de proteina (NX 6,25) em base seca, da farinha das sementes de L. albus, cultivadas no Brasil, variou de $38-40 \%$

OOMAH \& BUSHUK (1983) analisaram os teores de protelna e das frações proteicas solubilizadas de oito cultivares de duas espécies de tremoço ( $L$. albus e $L$. angustifoliusl, e encontraram uma variação consierável tanto no conteúdo como na solubilidade entre as espécies e também entre os cultivares. A variação de proteina para os cultivares de L. albus foi de $33-40 \%$, e para os de $L$. 
angustifolius de 36-37\%. Quanto às fraçชes proteicas obtidas nas duas espécies estudadas, acharam uma variação para as albuminas, globulinas e glutelinas de 2-10\%, 53-85\% e 10-35\%, respectivamente. Com relação a farinha desengordurada, os autores ainda afirmaram que a extraçăo da gordura afeta a solubilidade, promovendo um decréscimo na quantidade de albuminas e aumento de globulinas

VAZQUEZ et alii (1989) estudaram as protelnas de L. albus e L. Iuteus através de extração e filtração em coluna Sephadex, observaram que a distribuição de albuminas e globulinas, no L. Iuteus, foi de 17 e $58,4 \%$ respectivamente; enquanto que o L. albus apresentou maior teor de albumina $(58,4 \%)$ e menor de globulinas $(31,5 \%)$. Os autores analisaram, ainda a composiçăo química das sementes das duas espécies estudadas e observaram que quanto maior o extrato etéreo das sementes menor foi o conteúdo da protelna.

\section{4.5. Aminoácidos}

0 tremoço como vimos tem um alto teor de protelna, maior do que outras leguminosas, porém a qualidade nutricional da protelna e baixa uma vez que apresenta deficiencia de alguns aminoácidos essenciais. 0 primeiro aminoácido limitante, encontrado na protelna do tremoço foi a metionina, seguida pela cistina. (AGUILERA \& TRIER, 1978; GROSS \& VON BAER, 1977; SGARBIERI \& GALEAZZI, 1978). 
OOMASH \& BUSHUK (1983) estudaram a composição aminoácida das fraçðes protécicas de tremoço e verificaram que a fração albumina apresenta altas quantidades de lisina, histidina, treonina, glicina, alanina, valina e metionina e menores proporçठes de arginina, leucina e fenilalanina. A fração globulina, segundo os mesmos autores, está presente em maior proporção na protelna de tremoço (53-85\%) com uma composição aminoacidica inferior à albumina contendo quantidades baixas de lisina, treonina, prolina, glicina, alanina, valina e metionina.

TAHA \& EL-NOCKRASHY (1982) avaliaram o conteúdo de aminoácidos das farinhas de tremoço preparadas por trés diferentes métodos, e encontraram como aminoácidos limitantes a lisina triptofano e valina. Os autores avaliaram o conteúdo da cistina.

A composição aminoacidica de cinco espécies de tremoço foi estudada por MUzQUIz et alii (1989). Os autores encontraram que o conteúdo de lisina foi semelhante em todas as especcies, porém inferiores ao padrão aminoacidico recomendado pela FAO/WHO (1984). Os valores de triptofano para todas as espécies foram altos, superiores às recomendaçoes $\mathrm{FAO/WHO} \mathrm{(1984).}$

\subsection{Fatores antinutricionais presentes no tremoço}

Como frequentemente ocorre nas leguminosas, o uso do tremoço na alimentação é limitada pela presença de 
substáncias antinutricionais, que incluem principalmente os glicosldeos cianogênicos, hemaglutininas, alcalóides, inibidores de tripsina e ácido fítico. CONTRERAS et alii (1973) avaliaram o conteúdo de glicosideos cianogénicos em diversas leguminosas cultivadas no Chile, e encontraram que - tremoço apresentou valores de 0,42-0,46 $\mathrm{mg}$ HCN/100g de amostra seca. No mesmo trabalho os autores relataram que a legislação dos EUA e de alguns palses europeus permitem niveis de até $20 \mathrm{mg}$ HCN/100g da amostra seca.

A presença de hemaglutinas em várias leguminosas foram investigadas por CONTRERAS \& TAGLE (1974). Observaram que a atividade hemaglutinante de algumas leguminosas deram reação positiva com eritrócitos tripsinados de vaca e outras com eritrócitos tripsinados de coelho. 0 tremoço apresentou atividade hemaglutinante na diluição 7 somente nos eritrócitos de vaca. KIM \& MADHUSUDHAN (1988), relataram que a farinha desengordurada dos grãos de Lupinus angustifolius mostrou atividade hemaglutinante somente com eritrócitos tripsinados de coelho e que a atividade hemaglutinante foi estável numa faixa de temperatura de 40 a 80॰C, por 10. min, porém nenhuma atividade hemaglutinante foi observada quando a amostra foi submetida a temperatura de $900^{\circ} \mathrm{Cor} 8 \mathrm{~min}$.

Os grãos de tremoço amargo contém aproximadamente 2\% de alcalóide sobre o peso seco, e a ingestão de 11 a $25 \mathrm{mg}$ por quilograma de peso tem causado envenenamento em 
crianças. O envenenamento com alcalóides provoca sintomas como: caimbra, cianose, paralisia respiratória, dor estomacal violenta, vómito e dispnéia (AGUILERA \& TRIER, 1978). Segundo o mesmo autor, os alcalóides encontrados no tremoço săo identificados com lupanina, espartelna, lupinina, isolupanina, angustifolina e L-17-hidroxilupanina, sendo que os dois primeiros são os mais tóxicos e o último é aproximadamente dez vezes menos tóxico.

0 conteúdo de alcalóide em duas espécies de tremoço, encontrados em estudo realizado por BALLESTER et alii (1980) foi de 0,051 para o L. albus e 0,091 para o L. Iuteus, os quais não afetaram o crescimento de animais alimentados com dieta contendo as duas espécies de tremoço.

GUILLAUME et alii (1979) avaliaram o consumo de dietas contendo farinha de sementes de tremoço ( $L$. albus) amargo e doce, em galinhas. observaram que os animais que consumiram a dieta contendo tremoço amargo lalto teor de alcalóide) apresentaram diminuiçăo na ingestăo da dieta, no crescimento e na eficiéncia alimentar. Os alcalóides, segundo os autores provocam uma ação depressiva no apetite, - que pode ser ocasionada pelo gosto amargo apresentado pelas leguminosás que contém alto teor de alcalóides. MÚzQUIZ et alii (1989) relataram que os componentes antinutricionais (saponinas e ácido fltico) variam entre as espécies de tremoço e que o teor de alcalóide varia 
não só entre as espécies mas também entre os cultivares da mesma espécie.

Quanto aos inibidores de protelnas, GROSS \& VON BAER (1977) relataram que as especies $L$. albus e $L$. mutabilis não contém este fator antinutricional. AGUILERA \& TRIER (1978) informaram que L. albus apresenta baixas atividades antitriptica e de urease.

RAHMA \& NARASINGA RAO (1984) não encontraram inibidores de tripsina e de a-amilase na farinha de grãos de tremoço crus e de grãos submetidos a tratamento para eliminar o sabor amargo.

2.6. Tratamentos nos grăos de leguminosas para obtençăo de farinhas

Vários tratamentos tém sido realizados nos grãos de leguminosa visando melhorar as caracteristicas nutricionais e organolépticas das mesmas. Esses tratamentos normalmente envolvem emprego de calor (úmido ou seco) e maceração em água ou. soluçơes contendo substâncias químicas. OKAKA \& POTTER (1979) avaliaram à extração do "flavor" do feijão caupi atraves da maceraçăo dos grãos em água acidificada com $\mathrm{HCl}$ a $1 \%(\mathrm{pH} 2,0,4,0$ e 6,0), branqueadas, secas em tambor e moldas. Observaram que a maceração em água acidificada $(\mathrm{pH} 2,0,4,0$ e 6,0$)$, seguido de 
branqueamento, diminuiu o "flavor" de feijão, mais eficientemente do que a maceração em água somente acidificada.

O efeito da tostagem dos grãos de tremoço, em forno por 10, 20 e 30 minutos a temperatura de $90 \circ \mathrm{C}$, foi estudado por YAAEZ et alii (1986). Os autores relataram que a tostagem durante 10 minutos não afetou o conteúdo de aminoácidos sulfurados embora tenha sido observado lima perda minima de isoleucina e valina. A tostagem por 40 minutos promoveu uma perda significante nos teores de lisina e metionina + cistina. Quanto a avaliação da qualidade nutricional da protelna, os autores relataram que os valores de PER (Taxa de Eficiencia Proteica) foram 0,80; 0,92; 0,59; 0,53 e 0,46 para os grãos de tremoço cru, tostados por 10, 20,30 e 40 minutos respectivamente.

o outro método envolvendo calor seco foi realizado por JIBAJA \& BRESSANI (1988) onde obtiveram farinhas tostadas de feijão caupi, feijão canavalia e tremoço por meio de tratamento térmico em leito de areia a 150, 200 e $250 \circ$ C durante 2,5 minutos. Os grãos de tremoços antes de serem tostados em leito de areia foram macerados por 24 horas em água na proporção de 1:3 (grãos: água) e então submetidos a coç̧ão por 40 minutos. A maceração dos grãos de tremoço deve ser empregada previamente a qualquer tratamento, visando a eliminação de alcalóides (sabor amargo) nos mesmos. Segundo os autores, este tratamento prévio nos 
grãos de tremoço diminui de 60 a $70 \%$ o teor de alcalóides, chegando a valores de 0,02 e $0,002 \%$.

RAHMA \& NARASINGA RAO (1984) realizaram um tratamento para retirar sabor amargo dos grãos de tremoço e verificaram o efeito do tratamento sobre a composição de leguminosa. 0 tratamento consistiu em deixar as sementes macerando em água de torneira durante uma noite e a seguir coç̧ão das mesmas por 20 minutos. As sementes cozidas foram colocadas novamente em maceração durante 4 dias com quantidade de água tal que cobrisse as sementes, sendo a água de maceração trocada a cada 3 horas. No final, os grãos foram descascados, moldos duas vezes e então liofilizados. Os autores verificaram que o tratamento para remoção do sabor amargo aumentou o conteúdo da proteina, lisina disponivel e cinzas, causando decréscimo nos teores de taninos e açúcares, presentes nas sementes de tremoços.

O tratamento da semente do tremoço por lixiviação foi descrita por TAHA \& EL-NOCKRASHY (1982). 0 método constituiu na maceração em água de torneira durante uma noite e posterior fervura durante 30 minutos para prevenção da germinação. As sementes fervidas foram colocadas em maceração durante 4 dias trocando-se a água várias vezes ao dia. As sementes foram espalhadas em bandejas, secas em forno a $80 \circ \mathrm{C}$ e moldas.

Outro método também descrito pelo mesmo autor acima, foi o do tratamento dos grãos com sal de amónio para 
eliminação do sabor e odor. Por esse método houve aumento da solubilidade da protelna e maior conversão do amido em açúcares. O tratamento foi realizado colocando-se 1 quilo de grãos de tremoço limpos e sadios em solução contendo $2 \%$ de carbonato de amónio durante 10 horas a $26^{\circ} \mathrm{C}$. Após esse periodo, a solução foi drenada e os grãos colocados novamente em solução contendo $1 \%$ de carbonato de amónio e $3 \%$ de levedura ativa, durante 6 horas, a $50 \circ \mathrm{C}$, na proporçăo de $1: 1$ $(v / v)$. Ao término da maceração, os grãos foram autoclavados em baixa pressão, durante 15 minutos, moldos e liofilizados.

TAHA \& EL-NOCKRASHY (1982) relataram que o tratamento de lixiviaçăo foi altamente efetivo na eliminaçăo de alcalóides amargos dos grãos de tremoço, enquanto que o tratamento com carbonato de amónio não promoveu nenhum efeito significativo. Em relaçăo ao conteúdo de protelna, os valores aproximados, encontrados nos grãos de tremoço lixiviados e tratados com o carbonato de amónio foram 62 e $47 \%$, respectivamente.

SALES (1980) relatou que o bicarbonato de sódio reduz de aproximadamente $1 / 3$ o tempo de cocção de feijões, sem prejudicar o valor nutricional, sabor e textura, e pode ser adicionado ao remolio ou ao cozimento. A quantidade de bicarbonato de sódio que produziu melhores resultados sem danos ao feijão, foi de $0,25 \%$ em relação ao peso do feijão. A adição de $0,05 \%$ ou mais, provoca um 
amolecimento excessivo e reduz o teor de tiamina dos mesmos.

2.7. Complementação da farinha de tremoço e elaboração de produtos alimenticios

A complementação de cereais com leguminosas, oleaginosas é frequentemente usada para aumentar a ingestão de proteina, principalmente nos paises do terceiro mundo, onde o suprimento de protelnas é bastante limitado. A complementação não somente aumenta a ingestão de proteina, mas também favorece a utilização biológica da mistura resultante. O valor nutritivo de uma proteina pode ser analisado empregando-se métodos biológicos adequados onde se determina a digestibilidade e/ou assimilação da protelna de uma determinada mistura. Além da quantidade da protelna em produtos alimenticios complementados, outro fator que deve ser considerado na elaboração de misturas proteicas é o custo das mesmas (DREYER, 1986).

CAMPOS \& EL-DASH (1978) prepararam uma mistura de farinha de trigo com 5, 10, 15 e $20 \%$ de farinha de tremoço doce, analisaram as propriedades reológicas da massa e a qualidade do pão. Observaram que a adição de farintha de tremoço à farinha de trigo aumentou a absorção de água, tempo de crescimento e o indice de tolerância, diminuindo a 
estabilidade da massa. A extensibilidade da massa e a resistência máxima para a extensão também mostrou uma redução proporcional ao aumento da quantidade adicionada de tremoço. Quando o pão foi produzido em teste experimental de panificação, o uso de $5 \%$ de farinha de tremoço doce produziu um pão de qualidade similar ao pão controle. Embora - uso de $10 \%$ de farinha de tremoço doce ocasionou uma leve redução no volume e qualidade, a adição de $0,25 \%$ de CLS (estearil-lactil-lactato decalcio), aumentou o volume e melhorou a qualidade do pão.

A qualidade nutricional de pơes obtidos de farinha de trigo complementada com 7 e $10 \%$ de farinha de tremoço doce, foi avaliada por EL-DASH \& SGARBIERI (1980) atraves da análise biológica da protelna obtida na mistura. Os valores do PER (Taxa de Eficiencia Proteica) encontrados para os pães fortificados com 7 e 10\% de farinha de tremoço doce e o controle foram de $0,90,1,28$ e 0,81 , respectivamente.

BALLESTER et alii (1984) usaram a farinha de tremoço doce sem desengordurar para substituir 3, 6, 9 e $12 \%$ da farinha de trigo, na elaboração de pães. Os estudos reológicos da farinha, realizados pelos autores, mostraram que a absorção de água aumentou gradualmente de $60 \%$ para o trigo à $77 \%$ para a mistura de $12 \%$ de farinha de tremoço doce; o volume e o peso do pão aumentaram com a adição dos diferentes niveis de farintia de tremoço doce à farinha de 
trigo. 0 conteúdo de proteina no pão controle (farinha de trigo) foi de $10,3 \%$ e do pão elaborado com $9 \%$ de farinha de tremoço foi de $11,7 \%$. Os valores do PER para o pão controle e pão contendo $9 \%$ de farinha de tremoço doce foram 1,72 e 2,00, respectivamente. Os autores relataram ser possivel, substituir $9 \%$ da farinha de trigo por farinha de tremoço doce, na elaboração de pães.

ZACARIAS et alii (1985), estudaram a incorporação de 3, 6, 9 e $12 \%$ de farinha de tremoço a farinhạ de trigo, na fabricação de pães. As caracteristicas internas e externas dos pães (aparência, cor, aroma, textura e sabor) e aceitabilidade dos mesmos foram avaliados através da análise sensorial. Os resultados das caracteristicas internas e externas revelaram diferenças significativas entre os diferentes niveis de incorporação da farinha de tremoço doce, sendo que apenas a aparência, em todos os niveis de substituição, foi considerada boa. Quanto ao estudo de aceitabilidade realizado com o pão contendo $9 \%$ de farinha de tremoço, observaram ótima aceitação.

0 enriquecimento de biscoitos com 5, 10, 15, 20 e $25 \%$ de farinha de tremoço foi realizado por BALLESTER et alii (1986). A adição de 5\% e $25 \%$ de farinha de tremoço a farinha de trigo para elaboração de biscoito, mostrou valores para o conteúdo de proteina de $8,9 \%$ e 55,7\%, respectivamente. $0 \operatorname{PER}(1,92)$ foi encontrado quando os biscoitos foram enriquecidos com $20 \%$ de farinha de tremoço doce. 
PENNA et alii (1987) verificaram a aceitabilidade de biscoitos enriquecidos com $0,5,10,15,20$ e 25\% de farinha de tremoço doce. Qs estudos realizados em escolares mostraram boa aceitabilidade dos biscoitos enriquecidos com 0 e 10\% de farinha de tremoço doce.

Estudos sobre a avaliação sensorial e a aceitabilidade de dois tipos de pães (Halula e Marraqueta) comuns no Chile, foram realizados por PENNA et alii (1988). Observaram que a melhor qualidade dos dois tipos de pães foi obtida quando se adicionou $6 \%$ de farinha de tremoço doce à farinha de trigo. A adição de $9 \%$ de farinha de tremoço doce também apresentou bons resultados, sendo considerada pelos autores como uma alternativa de uso. A aceitabilidade entre escolares, de 9 a 10 anos de idade, para os dois tipos de pães com 0, 6 e $12 \%$ de farinha de tremoço foi muito boa.

CAMACHO et alii (1989) complementaram o milho híbrido e milho opaco-2 com 6, 8, 10 e $12 \%$ de farinha de tremoço doce, e avaliaram a qualidade nutricional de "Humitas", feitas com as farinhas de milho hibrido e milho opaco-2 complementados com os diferentes niveis de farinha de tremoço doce. A complementação com $8 \%$ de farinha de tremoço doce foi considerada ótima do ponto de vista nutricional e sensorial para o milho hibrido. Entretanto, os mesmos autores verificaram que o nivel de $8 \%$ de complementação não melhorou significativamente a qualidade nutricional do milho opaco-2, que por si só supera a qualidade do 
milho hibrido complementado. 0 processo de esterilização realizado nos enlatados de "Humitas" promoveu uma diminuição na qualidade nutricional e sensorial dos mesmos.

CATRICHEO et alii (1989) desenvolveram um alimento para crianças contendo $27,5 \%$ de farinha de trigo, $20 \%$ de farinha de tremoço e $20 \%$ de leite em pó (com 18\% de gordura) e adicionado de vitaminas e minerais. As farinhas de trigo e tremoço doce foram submetidas a un tratamento de cocção-extrusão, antes de serem misturadas com outros ingredientes. A análise aproximada da mistura trigo-tremoçoleite mostrou os valores de $18,7 \%$ de proteina e $12,5 \%$ de gordura, com um valor calórico de $427 \mathrm{kcal} / 100 \mathrm{~g}$. A análise de aminoácidos indicou que a mistura foi deficiente em metionina + cistina e treonina. A avaliação biológica da proteina revelou um PER de 2,6 para a mistura trigo-tremoçoleite e de 2,8 para a proteina controle (ovo). A proteina da mistura mostrou uma digestibilidade tão alta quanto a do ovo (85,6 a $85,0 \%$, respectivamente).

Além da utilização em produtos como pão, biscoitos e produtos alimenticios para crianças, os grãos de tremoço podem ser utilizados em outras matérias alimenticias como "tempeh". AGOSIN et alii (1989) inocularam esporos de Rizophus oligosporus nas sementes de tremoço para a elaboração do "tempeh". O processo de. fermentação dos grãos não melhorou as caracteristicas nutricionais dos mesmos, porém 
resultados preliminares da análise sensorial revelaram ser o "tempeh" de tremoço um alimento promissor.

PINTHONG et alii (1988) relataram que a fermentação do "leite de soja", com bactérias láctivas, promoveu uma melhora no "flavor" caracteristico, presente na leguminosa. Os autores adicionaram sabores e realizaram a análise sensorial obtendo bons resultados. 0 processo de fermentação ou elaboração do iogurte com o leite extraido dos grãos de tremoço, pode ser obtido utilizando o mesmo procedimento para a soja. Esse processo poderá visualizar a elaboração de um novo produto, o qual poderá ser uma alternativa na alimentação de individuos com intoleráncia a lactose. GALLAGER (1974), relatou sobre a importancia das bactérias láticas de leites fermentados e iogurte, as quais mesmo após a ingestão continuam a exercer a sua atividade de lactase (produção de lactase), eliminando os sintomas de diarréia e perda de cálcio pelas fezes nos individuos com intoleråncia à lactose. 


\section{MATERIAIS E MÉTODOS}

\subsection{Matéria prima}

Os grãos de tremoço branco doce (Lupinus albus var. Multolupa) foram fornecidos pela Cooperativa Regional Triticola Serrano de Ijui - S.C.

o arroz, semente de abóbora, ervilha e a farinha de trigo foram obtidos no comércio de Piracicaba. 0 milho opaco-2 foi fornecido pelo Departamento de Genética ESALQ/USP - Piracicaba - S.P. e o feijão caupi pelo Centro Nacional de Arroz e Feijão da EMBRAPA - Goiánia.

\subsection{Elaboração de farinhas}

3.2.1. Farinhas de tremoço

Os grãos de tremoço branco doce crus foram separados em 9 lotes, sendo que cada lote de grãos foi submetido a um determinado tratamento antes da obtenção da 
farinha. Os tratamentos realizados nos grãos de tremoço tiveram como finalidade a extraçăo do sabor amargo e o "flavor" de feijăo, caracteristico desta leguminosa, e a melhoria da qualidade nutricional da protelna, presente na mesma. Os tratamentos realizados foram os seguintes:

\subsubsection{Maceração em água contendo} bicarbonato de sódio

Us grãos inteiros de tremoço branco doce crus foram. descascados em descascador de martelo (TECNAL e as cascas foram separadas pneumaticamente utilizando aparelho soprador (TECNAL). Aos grãos descascados foi adicionado 0,25\% de bicarbonato de sódio, em pó, sobre a peso dos grãos, juntamente com água de torneira em ebuliçăo, na proporçăo 1:3 (peso/volume) e deixados em maceraçăo durante 1 hora. Após isso, os grãos foram lavados e cozidos em panelas de pressão (ROCHEDO - capacidade 5 1), sendo que a proporção de grăos de tremoço e água utilizados na cocção foi de 1:3 (peso:volume). O periodo de coç̧ăo foi de 20 minutos, o restante da água foi descartado e os grãos foram secos em estufa de circulação forçada (FANEM-modelo 330 ) com temperatura de $55^{\circ} \mathrm{C}$. Os grãos secos foram moldos em moinhos de faca (TECNAL) e transformados em farinha.

\section{$3 \cdot 2 \cdot 1 \cdot 2$. Tostagem dos grãos}

0 tratamento de torrefação foi realizado em 4 lotes, sendo que cada lote foi submetido à temperatura de 
$90 \circ \mathrm{C}$, em forno comum (BRASTEMP), em diferentes tempos. 0 primeiro lote foi torrado em 10 minutos, o segundo em 20 minutos, o terceiro em 30 minutos e o quarto em 40 minutos. Após a torrefação, os grãos foram resfriados e cada lote foi, separadamente, descascados em descascador de martelo, as cascas retiradas pneumaticamente em soprador e finalmente moldas em molnho de faca, obtendo-se quatro tipos diferentes de farinhas.

\subsubsection{Maceração em água destilada} acidificada com HCl a $0,12 \mathrm{~N}$

Trés lotes de grãos de tremoço doce crus foram colocados em maceração em água destilada acidificada com ácido cloridrico a 0,12 N, na proporção de 1:4 (peso/ volumel durante uma noite. Cada lote foi macerado cem água destilada acidificada, em $\mathrm{pH} 2,0,4,0$ e 6,0. Após a maceração, os grãos foram descascados, respectivamente lavados em água de torneira, branqueados durante 6 minutos em água em ebulição e batidos em liquidificador (WALITA - capacidade 1,5 1). A massa obtida foi espalhada em bandejas, secas em estufa de circulação forçada à $55 \circ \mathrm{C}$ e moidas em moinho de faca, obtendo-se trés tipos diferentes de farinha. 


\subsubsection{Maceração em água contendo}

metabissulfito de sódio

Os grãos de tremoço branco doce foram deixados em maceração em água de torneira na proporção de 1:3 (peso/volume), durante 1 noite. Os grăos de tremoço foram descascados, receberam a adição de $2 \%$ de metabissulfito de sódio, juntamente com água em ebulição, na proporção de 1:3 (peso/volume) e deixados em repouso nesta solução durante 1 hora. Após isso, a solução foi desprezada e as sementes lavadas em água de torneira. As sementes após a lavagem, receberam água de torneira na proporção de 1:3 e foram deixadas em maceração durante três dias, sendo que a água foi trocada duas vezes ao dia. Ao término deste período, grãos foram secos em estufa de circulação forçada à temperatura de $55^{\circ} \mathrm{C}$ e moldas em moinho de faca, obtendo-se assim a farinha.

Para fins comparativos elaborou-se uma farinha obtida apenas da moagem dos grãos de tremoço doce cru inteiros, sem tratamento prévio.

\subsubsection{Farinha de arroz}

A farinha de arroz polido foi preparada colocando-se em uma panela arroz e água na proporçăo de 1:2 (peso/volume) e cozinhando por 20 minutos. Após o cozimento, o arroz foi espalhado em bandejas, secos em estufa de 
circulação forçada à temperatura de $55^{\circ} \mathrm{C}$ e moldos em moinho de faca, obtendo-se a farinha.

\subsubsection{Farinha de semente de abóbora}

As sementes de abobora secas e cruas, inicialmente foram descascadas em descascador de martelo e retiradas as cascas no soprador. As sementes descascadas foram colocadas em uma peneira de malha fina, a qual foi adaptada a uma panela de capacidade de 3,5 l com aproximadamente 1,51 de água, de modo que as sementes não entrassem em contato com a água. Após a água atingir uma temperatura de $96^{\circ} \mathrm{C}$, as sementes permaneceram na peneira, recebendo - vapor de água durante 1:30h. Em seguida foram retiradas e colocadas em estufa de circulação forçada a $55^{\circ} \mathrm{C}$, para retirar toda umidade. As sementes secas foram prensadas em prensa hidráulica, para retirar parte do oleo. A extração do oleo restante, presente na torta obtida da prensagem, foi realizada em aparelho Soxhlet com $\mathbf{N}$-hexano, durante 8 horas. Em seguida a torta desengordurada foi colocada em estufa de circulação forçada a 55॰C por 12 horas, para evaporação do.. solvente, e moldas em moinhos de faca para obtenção da farinha. 


\subsection{Farinha de $\mathrm{ml}$ lho opaco-2}

Os grãos de milho opaco-2 foram parcialmente desintegrados em liquidificador industrial (TECNAL) e posteriormente moldos em moinhos de facas, obtendo-se a farintia.

\subsubsection{Farinha de ervilha}

As ervilhas frescas inteiras foram cozidas sob pressão, contendo erviliha e água na proporção de 1:2, durante 5 minutos. Após isso, as ervilhas cozidas foram espalhadas em bandejas e secas em estufas de circulação forçada a $55^{\circ} \mathrm{C}$. 0 material seco foi transformado em farinha através da moagem em moinho de facas.

\subsubsection{Farinha de fei jão caupi}

Os grãos de feijão cru e inteiros receberam a adição de 0,15\% de bicarbonato de sodio, em pó, sobre o peso seco dos grãos, juntamente com água em ebulição, na proporção de 1:3 (peso/volume), e deixados em maceração nesta solução durante 1 hora. Após esse procedimento, os grãos foram lavados e cozidos em panela de pressão, sendo que a proporção de feijăo e água utilizadas na cocção, foi de $1: 3$ (peso/volume). 0 períado requerido para cocção foi de 20 
minutos. Após a coç̧ão foram secos em estufa de circulação forçada a $55^{\circ} \mathrm{C}$ e moldos em moinho de facas, obtendo-se a farinha.

Todas as farinhas obtidas no laboratório e as adquiridas no comércio de Piracicaba, foram colocadas em sacos plásticos, fechados e armazenados em refrigerador a $5 \cdot C$.

\subsection{Preparo da mistura proteica}

As misturas proteicas foram realizadas com base no cômputo químico teórico dos aminoácidos essenciais da protelna da farinha dos diferentes grãos e da farinha de tremoço, obtendo-se as proporçơes ideais de cada farinha, destinadas à mistura. 0 escore de aminoácidos (EAA) foi feito comparando-se como os valores dos aminoácidos da protelna padrão da FAO (1984).

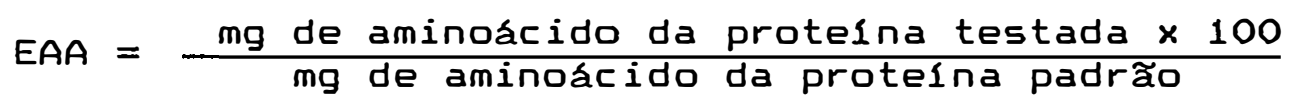

As farinhas de tremoço, obtidas de dois tratamentos: com metabissulfito de sódio e com água acidificada em pH 2,0, foram utilizadas na elaboração das misturas proteicas.

A farinha de tremoço obtida do tratamento com metabissulfito de sódio-foi utilizada para complementar a 
protelna das farinhas de arroz, de milho opaco-2, de trigo e de erviliha.

A farinha de tremoço obtida com água acidificada $\mathrm{pH}$ 2,0 foi utilizada para complementar a protelna das farinhas de semente de abobora, de arroz, de trigo e de feijão caupi.

\section{4. Preparo das dietas experimentais}

Foram elaborados dois tipos de dietas experimentais: dietas experimentais não complementadas e dietas experimentais complementadas. As dietas experimentais não complementadas foram obtidas com as farinhas de grăos de tremoço submetidos a diferentes tratamentos e de grãos de tremoço cru. As dietas experimentais complementadas foram obtidas com as misturas proteicas. Foram elaborados também uma dieta padrão contendo caseina e uma dieta aproteica.

As dietas experimentais não complementadas

foram as seguintes:

DI - farinha de tremoço cru;

DII - farinha de tremoço tostado por 10 minutos;

DII - farinha de tremoço tostado por 20 minutos;

DIV - farinha de tremoço tostado por 30 minutos;

DV - farinha de tremoço tostado por 40 minutos;

DVI - farinha de tremoço macerado em água com $\mathrm{pH}$ 2,0;

DVII - farinha de tremoço macerado em água com $\mathrm{pH}$ 4,0; 


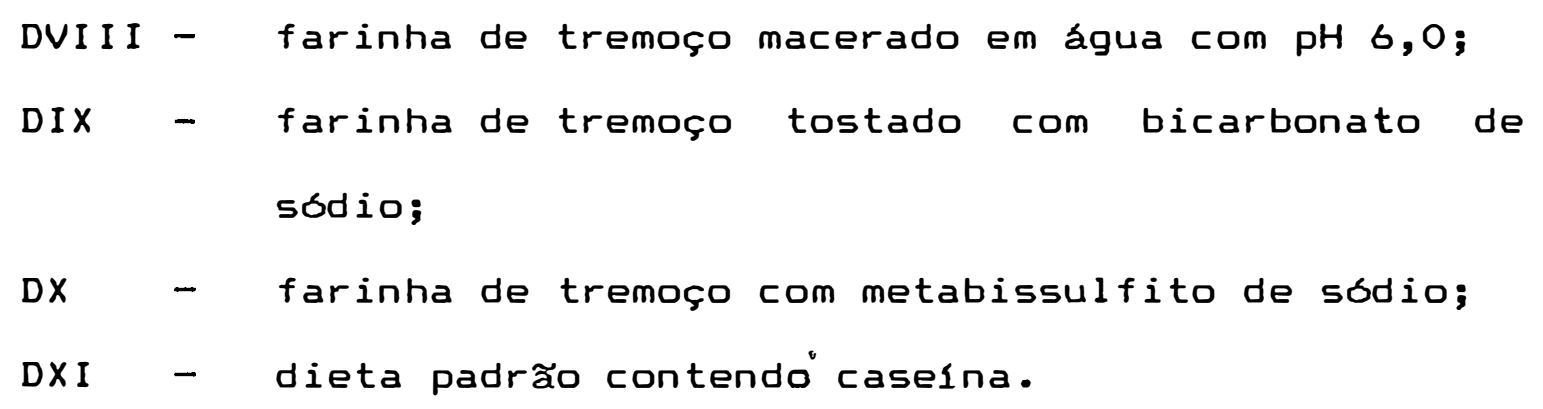

As dietas experimentais complementadas, como já relatado no preparo das misturas proteicas, foram elaborados com farinha de tremoço submetidas a dois tratamentos diferentes e misturados com farinha de outros grãos. Também foram elaboradas, novamente, uma dieta padrão contendo caseina e uma dieta aproteica.

As dietas experimentais complemientadas foram

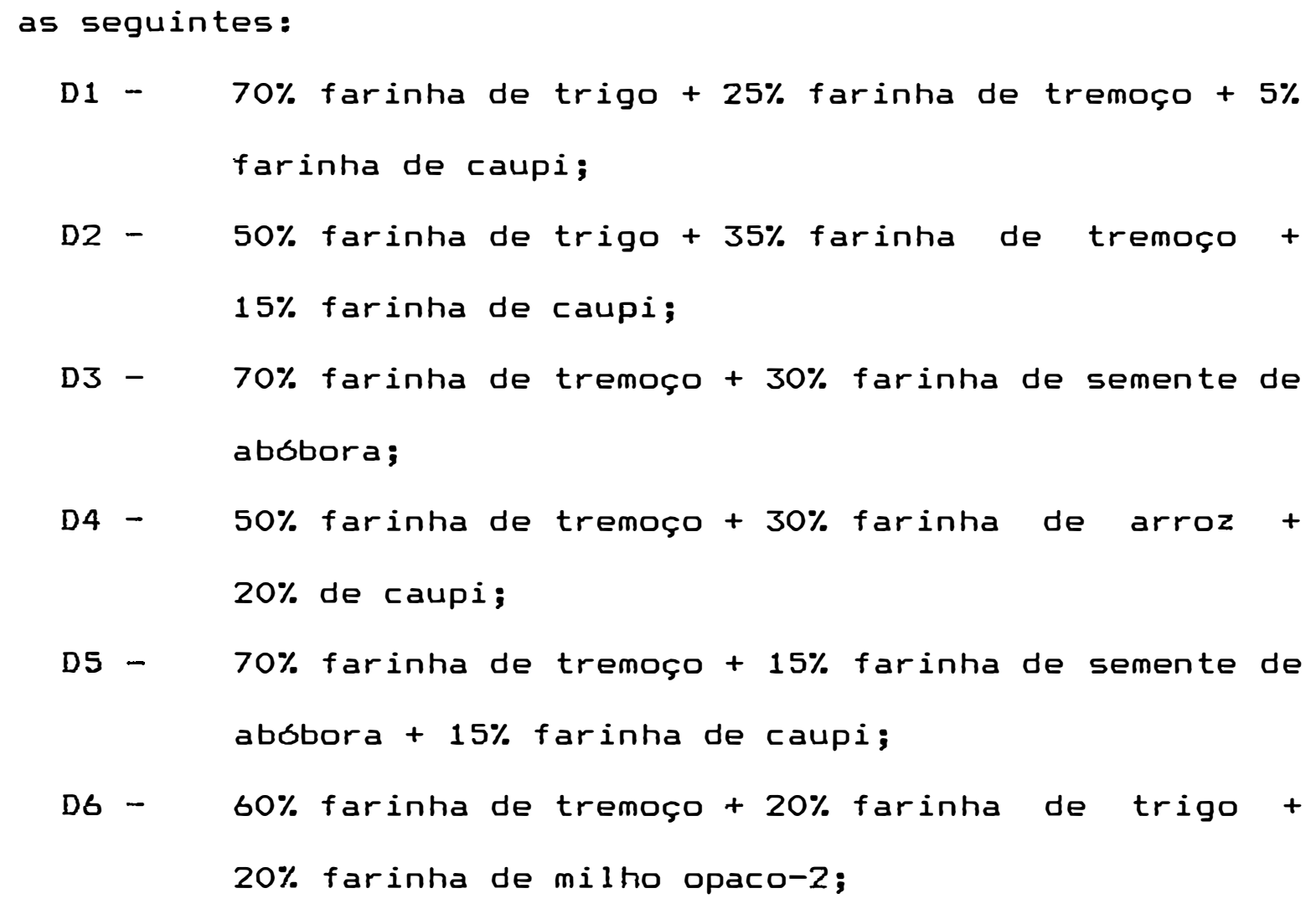




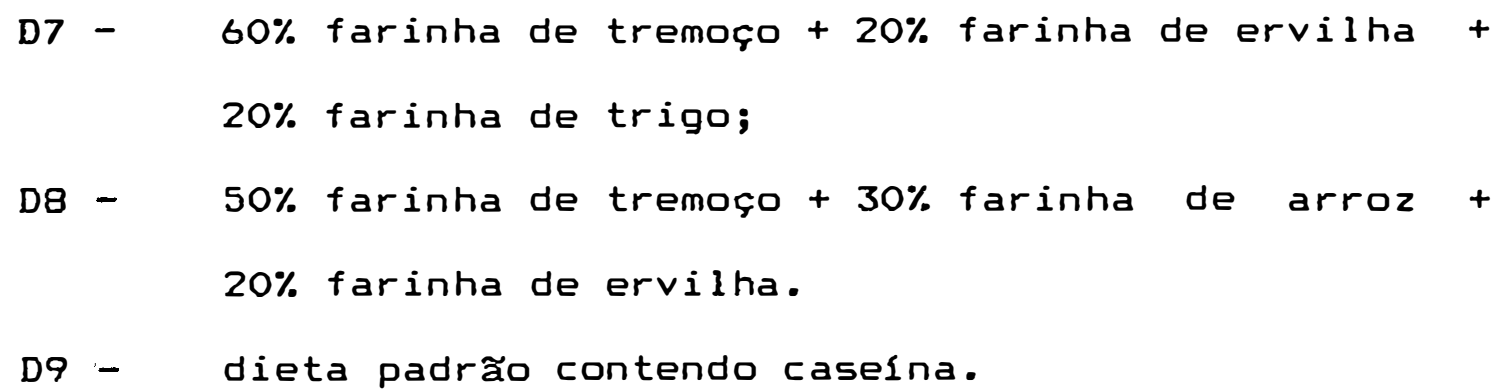

Todas as dietas experimentais e a padrão foram formuladas de acordo com o método estabelecido pela AOAC (1981) e continham: $10 \%$ de protelna; $1 \%$ de mistura vitaminica; $4 \%$ de mistura salina; $8 \%$ de $6 l e o$ e amido para completar $100 \%$. A dieta aproteica foi formulada com as -mesmas porcentagens das demais dietas, exceto quanto ao teor de proteína.

\subsection{Análise bromatológica}

As farinhas de tremoço, de trigo, de arroz, de ervilha, de semente de abóbora, de milho opaco-2, de feijão caupi, as dietas experimentais contedo farinhas de tremoço obtidas de diferentes tratamentos e as dietas experimentais elaborada com as misturas proteicas foram avaliadas quanto aos teores de umidade, proteina ( $N \times 6,25)$, extrato etéreo e umidade, de acordo com os métodos descritos pela AOAC (1981). 
A determinação de carboidratos totais e lactose foi realizada no extrato liquido, obtidos dos grãos de tremoço tratados com metabissulfito de sódio, no extrato IIquido adicionados de leite em pó desnatado e de iorgurte natural, antes da fermentaçăo e após fermentação com bactérias láticas, utilizando o método de determinação de lactose em leite, descrito por ABU-LEHIA (1987). 0 teor de lactose do extrato liquido fermentado foi obtido por diferença. Para fins comparativos foi determinado o teor de lactose do iogurte natural, seguindo o mesmo método de ABU-LEHIA (1987).

\subsection{Ensaio biológico}

o valor biológico das proteinas fornecidas pelas dietas experimentais e controle foram analisadas utilizanda-se para cada dieta 6 ratos machos, linhagem wistar, recém desmamados com idade entre 21 e 23 dias, obtidos no biotério do Setor de Nutriça e Alimentos - ESALQ/USP.

Os animais foram colocados em gaiolas individuais e receberam água e alimentos "ad libitum". 0 consumo de raçăo e ganho de peso foram verificados 3 vezes por semana, durante 28 dias, conjuntamente com a coleta e pessagem das fezes de cada animal. Ao.término desse período, os animais foram sacrificados, sua carcaça aberta longitudi- 
nalmente, secas em estufa a $105^{\circ} \mathrm{C}$ e moldas. As fezes coletadas também foram secas em estufa a $105^{\circ} \mathrm{C}$ e moldas.

As carcaças e fezes secas e moldas foram analisadas quanto ao teor de proteina, de acordo com a AOAC (1981).

Todos os dados coletados durante o ensaio biológico e os teores de protelna da carcaça e fezes foram utilizadas para os cálculos de D (Digestibilidade), NPU (Utilização Liquida da Proteśna), PER (Taxa de Eficiencia proteica) e VB (Valor Biológico).

Os dados coletados do grupo de animais que consumiram a dieta aproteica, durante o periodo experimental, foram utilizados para corrigir a protelna consumida e eliminada pelos animais dos grupos que consumiram as dietas experimentais e a padrão, afim de realizar o cálculo da digestibilidade e NPU.

Os cálculos ( $D$, NPU, PER, CEA e VB) foram feitos da seguinte forma:

Digestibilidade (D):

$D=\frac{I-(F+F k)}{I} \times 100$, onde

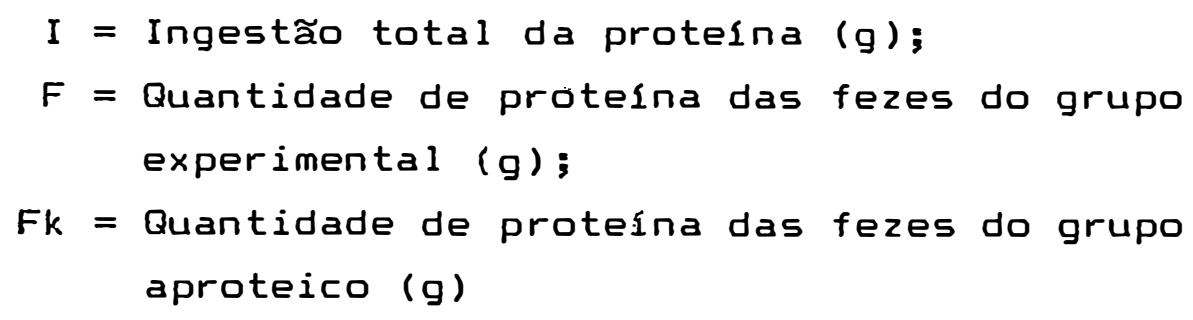


Utilização Líquida da Protelna CNPUD:

$$
\text { NPU }=\frac{B-B K-I K}{I} \times 100, \text { onde: }
$$

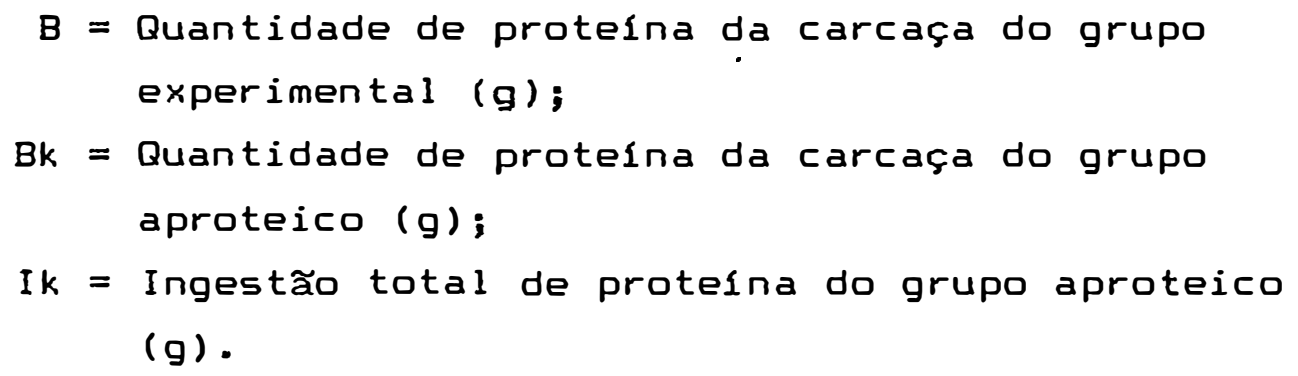

Taxa de Eficiéncia proteica (PER): PER $=\frac{\text { gantio de peso }(g)}{\text { consumo de proteina }(g)}$

Coeficiente de Eficácia Alimentar (CEA): CEA $=\frac{\text { gantio de peso }(g)}{\text { consumo de ração }(g)}$
Valor Biológico $(\mathrm{VB})$ :
$V B=\frac{N P U}{D}$

3.7. Preparo do extrato liquido ou "leite de tremoço"

Ds grãos de tremoço branco doce foram deixados em maceração em água de torneira, na proporção de 1:3 (peso/volume), durante 1 noite. Os grãos macerados foram 
descascados, receberam a adiçăo de $2 \%$ de metabissulfito de sódio, juntamente com água em ebulição na proporção de 1:3 (peso/volume) e deixados em repouso nesta solução durante 1 hora. Após isso, a solução foi desprezada e os grăos foram lavados e moldos em liquidificador comum. A moagem foi feita colocando-se para cada copo de semente úmida um copo e meio de água filtrada, em seguida o produto obtido da trituração foi torcido em pano próprio para elaboração de queijo, obtendo-se assim o extrato liquido de tremoço ou "leite de tremoço".

A escolha do tratamento com metabissulfito de sódio na elaboraçăo do "leite de tremoço" foi porque ele promoveu uma clarificaçăo nos grãos de tremoço, tornando o extrato liquido com aparéncia semelhante ao leite, e reduziu acentuadamente o sabor amargo dos grăos de tremoço.

3.8. Elabóração do produto fermentado com bactérias láticas ou "iogurte de tremoço"

o extrato liquido ou "leite de tremoço" foi aquecido em banho-maria com temperatura entre $70-80 \cdot \mathrm{C}$, durante 40 minutos e então resfriado à $40 \circ \mathrm{C}$. Quando a temperatura desejada $(40 \circ C)$ foi atingida, o produto recebeu a adição de 10\% de leite em pó desnatado (Molico) e 10\% de iogurte natural (Danone), sendo em seguida mantido em estufa à $42{ }^{\circ} \mathrm{C}$, durante 8 horas, para fermentaçăo. 
Com o objetivo de se verificar as caracteristicas sensoriais do produto fermentado, foi elaborado "iogurte de tremoço" com três sabores: abacaxi, morango e chocolate, e também iogurte natural (leite), com os mesmos sabores, para fins comparativos.

\subsection{Análise de minerais}

A análise de minerais foi realizada no extrato liquido de tremoço ou "leite de tremoço", e no produto fermentato com bactérias láticas ou "iogurte de tremoço", de acordo com o método descrito por SARRUGE \& HAAG (1974).

\subsection{Análise sensorial}

Os "iogurte de tremoço" e iogurte natural foram submetidos à análise sensorial utilizando os métodos de sensibilidade e preferência, descritos por MORAES (1981). Através do método de sensibilidade, os degustadores analisaram as caracteristicas como: acidez, sabor, aroma, cor e textura de cada produto, e com a metodo de preferéncia escolheram aqueles que mais lhe agradaram (Formulario Apêndice).

0 painel de degustadores foi montado com doze individuos adultos que receberam as amostras dos iogurtes em 
copinhos de polietileno de $60 \mathrm{~cm}$, identificados com números casuais de 3 digitos.

Os resultados obtidos através do método da sensibilidade foram determinados pelo total de pontos alcançados pela soma dos valores atribuidos a cada caracteristica. Através do total de pontos, os produtos foram classificados como:

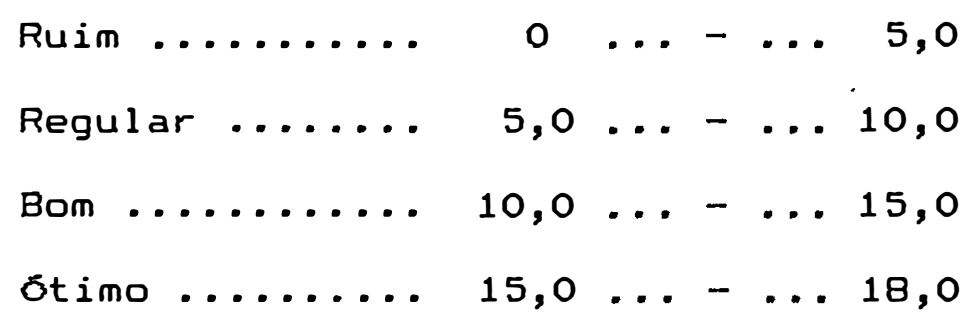

A preferéncia do produto foi realizada através da escala hedónica de 5 pontos, onde as provadores expressaram o quanto gostaram ou desgostaram dos sabores de "iogurtes de tremoço;". A escala e os valores atribusdos a ela foram os seguintes:

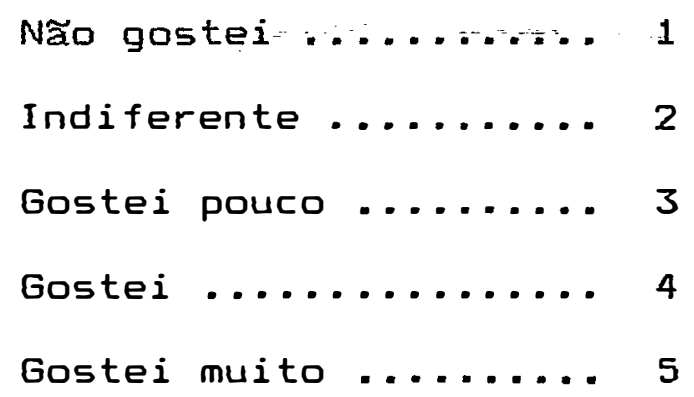

(Formulário da análise sensorial - Apéndice) 


\subsection{Analise estatistica}

0 modelo estatistico utilizado, tanto para o ensaio biológico como para a análise sensorial foi blocos inteiramente casualizados. Os dados obtidos no ensaio biológico foram analisados através da análise de variåncia e o teste de Tukey (comparação de médias). Os dados da análise sensorial foram analisados através da análise descritiva (GOMES, 1987). 


\section{RESULTADOS E DISCUSSĀO}

\section{1. Farinhas}

As farinhas de tremoço obtidas através dos diferentes tratamentos foram de cor amarelo claro, com odor característico, e a farinha obtida do tremoço cru apresentou-se com coloração amarelo um pouco mais escuro do que as demais. 0 rendimento médio das farinhas foi de $38 \%$ em relação ao peso dos grãos, antes de cada tratamento. As farinhas de tremoço obtidas através dos tratamentos dos grãos por tostagem; em água destilada acidificada e com bicarbonato de sódio apresentaram um sabor amargo, enquanto que no tratamento com metabissulfito de sódio o sabor amargo quase não foi percebido.

As farinhas produzidas no laboratório e utilizadas para complementar a proteina da farinha de tremoço foram as de arroz, semente de abóbora, feijão caupi e milho opaco-2. Os rendimentos obtidos na produção das mesmas foram 95, 29, 35 e 97\%, respectivamente. 
Todas as farinhas processadas passaram através de uma peneira de 30 "mesh" $(1,8 \mathrm{~mm})$, antes de serem utilizadas na preparaçăo das dietas experimentais.

\subsection{Análise bromatológica}

\subsubsection{Farinhas}

Os resultados das analises bromatológicas das farinhas de tremoço obtidas através dos tratamentos de tostagem, maceração em água destilada acidificada e com metabissulfito de sódio são apresentadas na Tabela 1.

Observando a-Tabela 1, verifica-se que o conteúdo de proteina e o extrato etéreo foi superior nas farinhas obtidas dos grãos tratados, em relação ao tremoço cru. As cascas dos grãos de tremoço foram retiradas em todos os tratamentos efetuados, exceto no tremoço cru, e isso pode ter favorecido o aumento no conteúdo de protelna e gordura nas farinhas obtidas dos grãos. que foram submetidos aos diferentes tratamentos. 
Tabela 1 . Composição bromatológica das farinhas de tremoço obtidas por diferentes tratamentos.

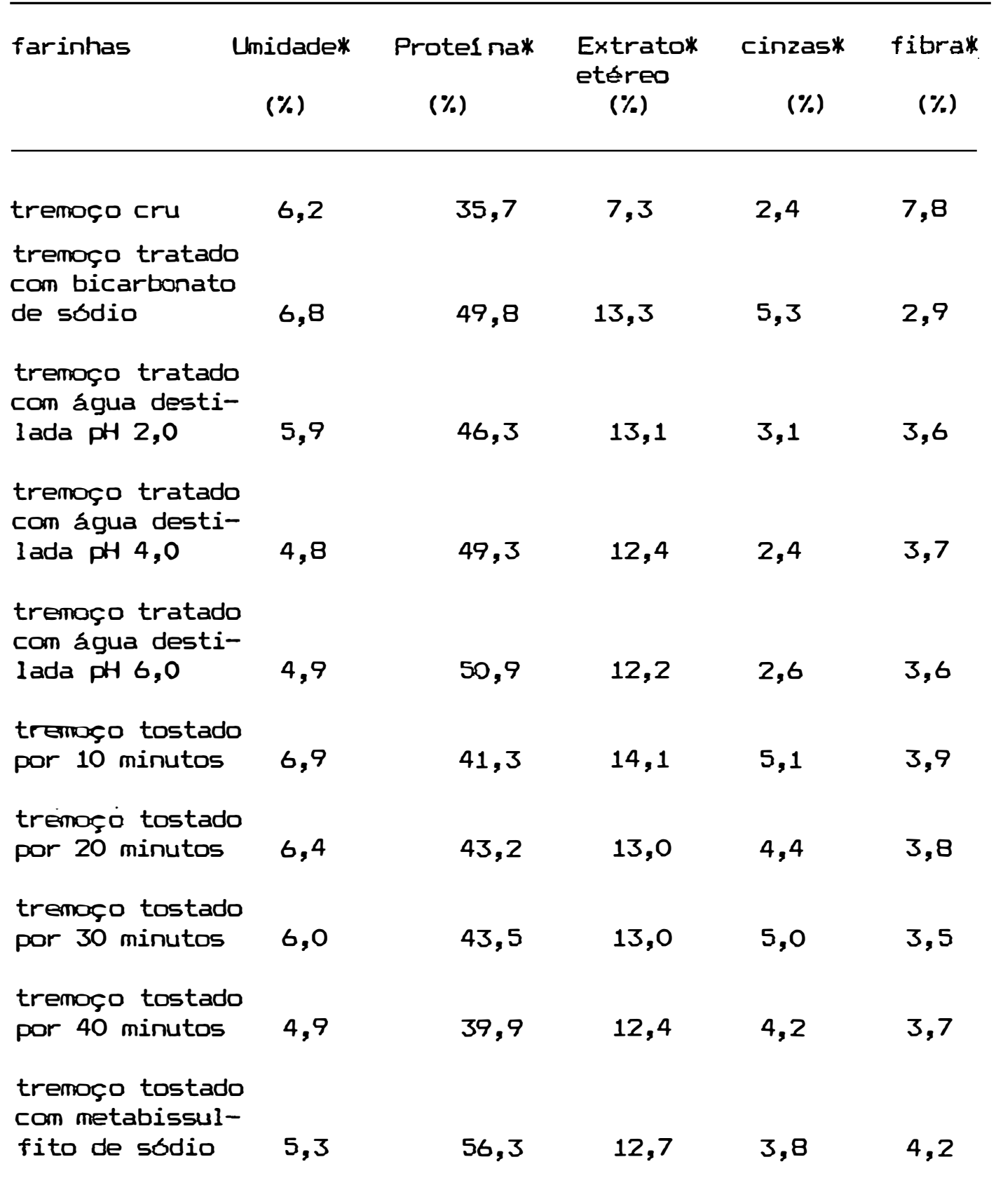

* Valores medios de 3 repetições 
Os dados encontradọs para a farinha obtida do grão de tremoço cru, foram inferiores aos relatados por TAHA \& EL-NOCKRASHY (1982), em termos de protelna $(38,9 \%)$, gordura $(9 \%)$, cinzas $(3,6 \%)$, fibra $(15,3 \%)$. OOMAH \& BUSHUK (1983), relataram que a composição química dos grãos de tremoço varia entre as variedades de uma mesma espécie, o que justifica a diferença existente entre as resultados encontrados e os mencionados por outros pesquisadores.

TAHA \& EL-NOCKRASHY (1982) observaram um aumento no conteúdo de proteina nos grãos de tremoço tratados com sal de amónio e posteriormente macerados em água $(46,9 \%)$ em relação ao grão cru (38\%). Isso mostra uma concordância entre os dados apresentados neste trabalho e os mencionados pelos referidos autores.

0 aumento no conteúdo de protelna foi maior nas farinhas dos grãos submetidos a tratamento com água destilada acidificada, com bicarbonato de sódio e com metabissulfito de sódio, os quais podem ter promovido um aumento na digestibilidade das protelnas das referidas farinhas.

As farinhas de trigo, arroz, semente de abóbora, ervilha, milho opaco-2 e feijă caupi, utilizadas para complementar a farinha de tremoço, foram analisadas quanto a conteúdo de umidade, protelna, extrato etéreo, cinzas e fibra. Os resultados são mostrados na Tabela 2. 
Tabela 2. Composição bromatológica das farinhas.

\begin{tabular}{lccccc}
\hline Farinhas & $\begin{array}{c}\text { Umidade } \\
(\%) * *\end{array}$ & $\begin{array}{c}\text { Proteina } \\
(\%) * *\end{array}$ & $\begin{array}{c}\text { Extrato } \\
\text { etereo } \\
(\%) * *\end{array}$ & $\begin{array}{r}\text { Cinzas } \\
(\%) * *\end{array}$ & $\begin{array}{c}\text { Fibra } \\
(\%) * *\end{array}$ \\
\hline $\begin{array}{l}\text { trigo } \\
\text { arroz }\end{array}$ & 10,10 & 14,00 & 0,91 & 2,4 & 0,65 \\
$\begin{array}{l}\text { semente de } \\
\text { abóbora }\end{array}$ & 8,6 & 8,75 & 2,1 & 0,18 & 1,15 \\
$\begin{array}{l}\text { ervilha } \\
\text { milho } \\
\text { opaco-2 }\end{array}$ & 5,30 & 25,40 & 1,80 & 5,1 & 6,79 \\
$\begin{array}{l}\text { feijão } \\
\text { caupi }\end{array}$ & 7,30 & 12,60 & 0,75 & 2,9 & 0 \\
\hline
\end{tabular}

* não determinada

* valores médiós de 3 repetiçơes

A farinha de trigo utilizada na complementaçăo apresentou resultados superiores daqueles relatados por BALLESTER et alii (1986), quanto à protelna $(10,1 \%)$, cinzas $(2,4 \%)$, fibra $(0,06 \%)$ e inferiores em relação à umidade $(11,8 \%)$ e.extrato etéreo $(1,5 \%)$. CATRIC̣HEO et alii (1989), encontraram na farinha de trigo, valores de 7,2, 15,2, 4, 1 e $2 \%$ no que se refere ao conteúdo de umidade, proteinas, extrato etéreo, fibra e cinzas, respectivamente.

A composição bromatológica da farinha de arroz foi superior à relatada por SCHOENEBERGER et alii (1982), quanto aos valores de umidade $(4,4 \%)$, proteina $(7,4 \%)$, extrato etéreo $(1,1 \%)$, cinzas $(0,8 \%)$ e fibra crua $(0,3 \%)$ 
No que se refere à farinha de milho opaco-2, os valores encontrados foram superiores aos mostrados por CAMACHO et alii (1989), quanto à protelna $(9,03 \%)$ e cinzas $(1,57 \%)$ e inferiores em relação ao extrato etéreo $(5,45 \%)$ e fibra $(1,48 \%)$.

Qs resultados encontrados para a farinha de feijão caupi foram superiores aos encontrados por LAGO et alii (1971), no que se refere à umidade $(5,78 \%)$, protelna $(24,90 \%)$ e fibra $(1,41 \%)$; quanto à gordura os resultados foram semelhantes $(2,12 \%)$, porém, em relação às cinzas $(3,10 \%)$, nossos resultados foram inferiores.

A maioria das leguminosas apresentam fatores antinutricionais nos seus grãos, porém, alguns são inativados pelo calor e outros săo eliminados pela maceração em água. KIM \& MADHUSUDHAN (1988), relataram que a hemaglutina presente em grãos de tremoço foi inativada à temperatura de $90 \circ \mathrm{C}$ por 8 minutos. GROSSS \& VON BAER (1977), relataram que - conteúdo de alcalóides pode ser eliminado com a fervura e posterior maceração em água durante 3 dias.

Uma vez que os grãos de tremoço foram tratados empregando-se calor seco ou úmido, segu'ido ou não de maceração, não se justifica os estudos dos fatores antinutricionais. 


\subsubsection{Dietas experi mentais}

As dietas experimentais elaboradas com' farinhas de tremoço submetidas a diversos tratamentos e com as farinhas de tremoço complementadas foram avaliadas quanto a análiise bromatológica. Os resultados são apresentados nas Tabelas 3 e 4 , respectivamente.

Analisando a composição bromatológica das dietas elaboradas com as farinhas dos grãos de tremoço cru e dos grãos submetidos a diferentes tratamentos constatou-se que o conteúdo de cinzas foi menor para as dietas VI, VII, VIII, IX e X do que para as demais. Esse decréscimo pode ter ocorrido em função do tratamento de maceração em água ter provocado nos grãos o arraste de minerais solúveis em água.

Quanto a composição bromatológica das farinhas complementadas, observou-se que o conteúdo de fibra, foi maior nas dietas $3,5,7$ e 8 , as quais continham farinhas de semente de abóbora ou farinhas de ervilhas. A farinha de semente de abóbora, como mostra a Tabela 2 , contém uma alta quantidade de fibra que justifica os valores encontrados nas dietas 3 e 5 . Embora o conteúdo de fibra da farinha de ervilha não tenha sido determinada, considerase que este seja a responsável pela quantidade de fibra das dietas 7 e 8, já que foram elaboradas sem ser descascadas. 
Tabela 3 . Composiçăo bromatológica das dietas experimentais elaboradas com farinhas de tremoço submetidas a diversos tratamentos.

\begin{tabular}{|c|c|c|c|c|c|c|}
\hline $\begin{array}{l}\text { Dietas } \\
\text { riment }\end{array}$ & $\begin{array}{l}\text { expe- } \\
\text { zais }\end{array}$ & $\begin{array}{c}\text { midade* } \\
(\%)\end{array}$ & $\begin{array}{c}\text { Protel na* } \\
(\%)\end{array}$ & $\begin{array}{c}\text { Extrato } \\
\text { etéreo* } \\
(\%)\end{array}$ & $\begin{array}{c}\text { Cinzas* } \\
(\%)\end{array}$ & $\begin{array}{c}\text { Fibra* } \\
(\%)\end{array}$ \\
\hline I & tremoço cru & 9,0 & 9,9 & 7,9 & 7,8 & 1,9 \\
\hline I I & $\begin{array}{l}\text { tremoço tostado } \\
\text { (10 min.) }\end{array}$ & 9,8 & 10,0 & 8,2 & 8,2 & 1,2 \\
\hline I I I & $\begin{array}{l}\text { tremoço tostado } \\
\text { (20 min.) }\end{array}$ & 7,6 & 10,2 & 8,0 & 8,0 & 1,1 \\
\hline IV & $\begin{array}{l}\text { tremoço tostado } \\
\text { (30 min.) }\end{array}$ & 8,7 & 10,2 & 8,1 & 8,1 & 1,0 \\
\hline v & $\begin{array}{l}\text { tremoço tostado } \\
\text { ( } 40 \mathrm{min.} \text { ) }\end{array}$ & 7,1 & 9,9 & 8,0 & 8,0 & 1,0 \\
\hline VI & $\begin{array}{l}\text { tremoço macerado } \\
\text { em água destila- } \\
\text { da pH } 2,0\end{array}$ & 10,0 & 10,0 & 8,0 & 5,9 & 1,2 \\
\hline VII & $\begin{array}{l}\text { tremoço macerado } \\
\text { en água destila- } \\
\text { da pH } 4,0\end{array}$ & 7,3 & 10,1 & 8,1 & 4,9 & 1,1 \\
\hline VIII & $\begin{array}{l}\text { tremaço macerado } \\
\text { em água destila- } \\
\text { da PH } 6,0\end{array}$ & 7,1 & 10,1 & 8,2 & 3,4 & 1,0 \\
\hline IX & $\begin{array}{l}\text { tremoço tratado } \\
\text { com bicarbonato } \\
\text { de sódio }\end{array}$ & 8,5 & 10,2 & 8,1 & 4,1 & 0,9 \\
\hline$x$ & $\begin{array}{l}\text { tremoço tratado } \\
\text { com metabissul- } \\
\text { fito de sódio }\end{array}$ & 5,3 & 10,2 & 8,1 & 3,8 & 1,0 \\
\hline
\end{tabular}

* Valores médios de 3 repetições. 
Tabela 4 . Composiçăo bromatológica das dietas experimentais elaboradas com as farinhas de tremoço complementadas.

\begin{tabular}{|c|c|c|c|c|c|c|}
\hline \multicolumn{2}{|c|}{$\begin{array}{l}\text { Dietas experimen- } \\
\text { tais complementa- } \\
\text { das }\end{array}$} & $\begin{array}{l}\text { midade } \\
(\%)\end{array}$ & $\begin{array}{c}\text { Protel na* } \\
(\%)\end{array}$ & $\begin{array}{c}\text { Extrato } \\
\text { etereo } \\
(\%)\end{array}$ & $\begin{array}{c}\operatorname{Cinzas^{*}} \\
(\%)\end{array}$ & $\begin{array}{c}\text { Fibra } \\
(\%)\end{array}$ \\
\hline 1 & $\begin{array}{l}\operatorname{trigo}(70 \%)+\text { tremo- } \\
\text { co(25\%) + caupi } \\
(5 \%)\end{array}$ & 9,5 & 10,1 & 7,9 & 1,26 & 0,10 \\
\hline 2 & $\begin{array}{l}\text { trigo }(50 \%)+\text { tremo- } \\
50(35 \%)+\text { caupi } \\
(15 \%)\end{array}$ & 10,0 & 9,9 & 8,3 & 2,78 & 0,61 \\
\hline 3 & $\begin{array}{l}\text { tremoço }(70 \%)+\text { semen- } \\
\text { te de absbora } \\
(30 \%\end{array}$ & 8,8 & 10,1 & 8,0 & 2,94 & 1,55 \\
\hline 4 & $\begin{array}{l}\text { tremoço(50\%) + arroz } \\
(30 \%)+\text { caupi } \\
(20 \%)\end{array}$ & 9,1 & 10,1 & 8,1 & 1,16 & 1,07 \\
\hline 5 & $\begin{array}{l}\text { tremoço(70\%) + semen- } \\
\text { te de abóbora }(15 \%)+ \\
\text { caupi }(15 \%)\end{array}$ & 9,7 & 10,2 & 7,9 & 2,14 & 1,61 \\
\hline 6 & $\begin{array}{l}\text { tremoço(60\%) + trigo } \\
(20 \%)+\text { milho opaco-2 } \\
(20 \%)\end{array}$ & 8,9 & 9,9 & 7,9 & 3,30 & 0,79 \\
\hline 7 & $\begin{array}{l}\text { tremoço(60\%) + ervilha } \\
(20 \%)+\text { trigo } \\
(20 \%)\end{array}$ & 10,0 & 10,1 & 8,1 & 2,90 & 1,51 \\
\hline 8 & $\begin{array}{l}\text { tremoco }(50 \%)+\text { arroz } \\
(30 \%)+\text { ervilha } \\
(20 \%)\end{array}$ & 9,9 & 10,1 & 8,2 & 3,80 & 1,48 \\
\hline
\end{tabular}

* Valores médios de 3 repetições 
A dieta 1 apresentou um teor de fibra inferior as demais dietas, apesar de conter farinha de feijão caupi $(7,15 \%$ de fibra) na sua constituiçăo. No entanto, a proporção de farinha de feijăo caupi (5\%) utilizada na elaboração da dieta 1 foi baixa, o que justifica o baixo teor de fibra presente na mesma.

\section{3. Ensaio biológico}

o ensaio biológico foi realizado em duas etapas. A primeira visando avaliar a qualidade da proteina das farinhas de tremoço obtidas dos diversos tratamentos, e a segunda para verificar o efeito da complementaçăo da farinta de tremoço com as farinhas de outros grăos. 0 ensaio biológico foi realizado com ratos albinos machos (Ratus novergicus) variedade Wistar e as variáveis estudadas foram ganho de PESO, PER, NPU\%, VB, CEA e D\%.

o teste estatı́stico aplicado para comparação entre as médias de tratamentos, nos demais ensaios biologicos foi o de Tukey (GOMES, 1987).

\subsubsection{Primeiro ensaio biológico}

A Figura 1 mostra a média do ganho de peso dos animais pertencentes a cada dieta estudada. 


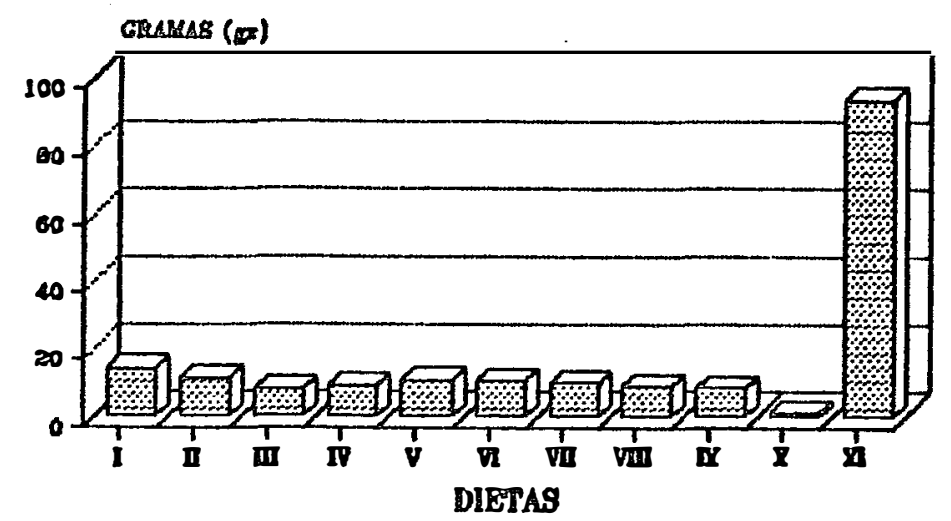

Foraraver OP

Figura 1. Ganho de peso dos animais, referente a cada dieta, durante 01 ensaio biológico.

Através da análise estatística aplicada, observou-se que o ganho de peso (GP) dos animais que consumiram, a dieta XI (caseina padrão) apresentou diferença altamente significativa a nivel de 5 e $1 \%$ em relação às demais dietas. Para a dieta $x$, observou-se uma diferença significativa à nível de $5 \%$ quando comparada com as demais.

As dietas I, II, III, IV, V, VI, VII, VIII e IX não apresentaram diferenças significativas entre si, mostrando que os tratamentos realizados nos grãos de tremoço cru não melhoram a qualidade do grão.

o tratamento com metabissulfito de sódio promoveu uma redução na qualidade nutricional da proteína do tremoço, quando se considerou o ganho de peso; como uma variável isolada. 
Uma vez que não houve diferenças entre as farinhas de tremoço cru e as farinhas de tremoço submetidas a diferentes tratamentos, concluiu-se que a variedade estudada não possuia fatores antinutricionais e que o baixo ganho de peso observado nos animais alimentados com as dietas contendo tremoço deveu-se provavelmente a baixa qualidade da protelna, ou seja, deficiência de aminoácidos essenciais (principalmente sulfurados) nos grãos da referida leguminosa.

Os valores médios do Coeficiente de Eficácia Alimentar (CEA) e a Taxa de Eficiência Proteica (PER) são mostrados nas figuras 2 e 3 onde observa-se que para as duas variáveis (CEA e PER) houve diferença altamente significativa a nivel de $5 \%$ e $1 \%$ entre a dieta de caseina (XI) e as demais tratamentos. Os resultados também mostraram para o PER e CEA, a nivel de $5 \%$ que os tratamentos de tostagem dos grãos por 20 minutos (III), com bicarbonato de sódio (IX) e com metabissulfito de sódio $(X)$ não foram significativamente diferentes entre si porém, a nivel de $1 \%$ houve diferença significativa entre o tratamento $(X)$ e os demais. Como pode ser constatado os tratamentos realizados nos grăos de tremoço cru não melhoraram sua qualidade nutricional sendo que algum tratamento pode até interferir negativamente com o metabissulfito de sódio, que reduziu a qualidade da proteina necessária para garantir o crescimento e o ganho em peso adequado dos animais. 


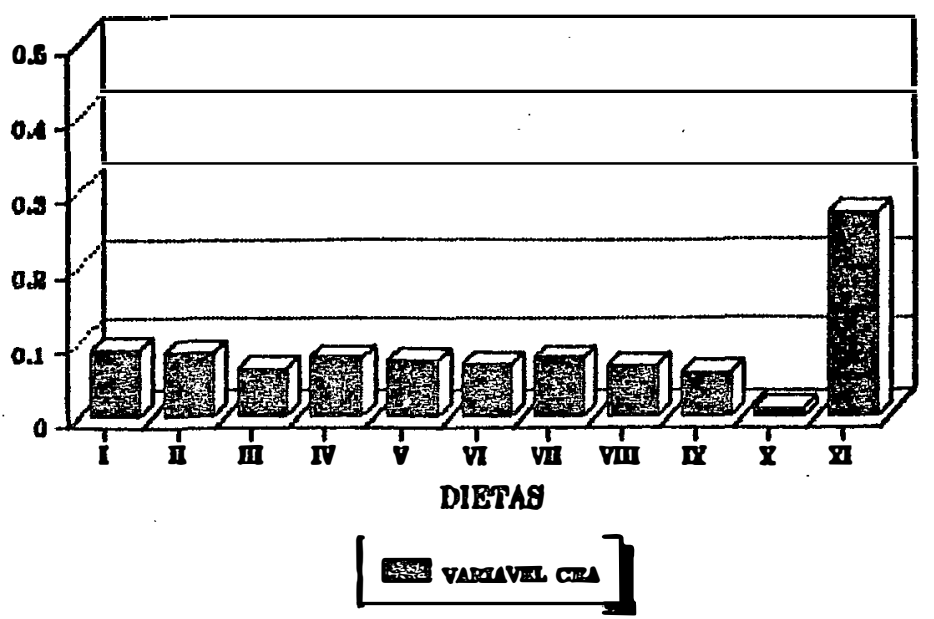

Figura 2. Valores do Coeficiente de Eficácia Alimentar (CEA), referente a cada dieta, durante o $1 . \mathrm{en}^{-}$ saio biológico.

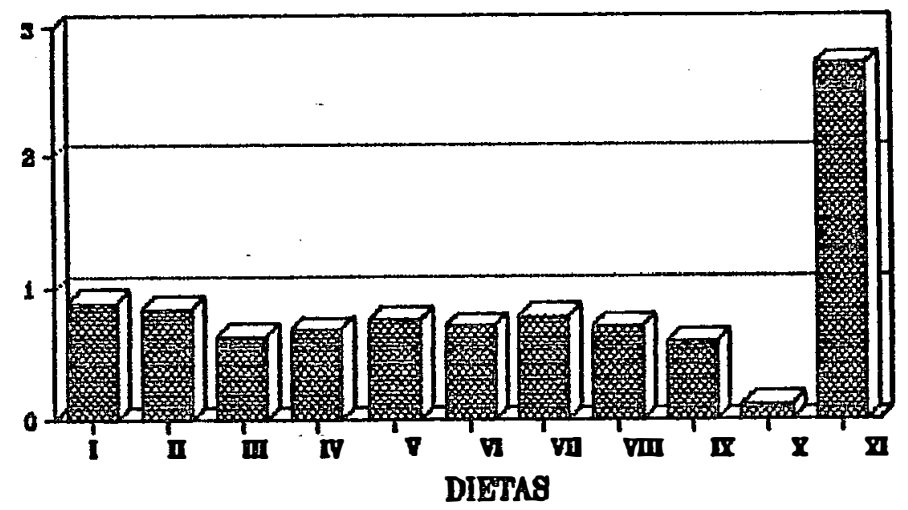

F尊 VATAVIL P.

Figura 3. Valores da Taxa de Eficiência Proteica (PER), referente a cada dieta, durante o $1^{\circ}$ ensaio biologico. 
o PER obtido para a farinha de tremoço cru foi superior aos valores relatados por YAAEZ et alii (1986) $(0,78)$ e BALLESTER et alii (1980) $(0,48)$. Os valores do PER para as farinhas de tremoço tostado por $10,20,30$ e 40 minutos relatados por YAAEZ et alii (1986) foram inferiores $(0,51$ e 0,92) aos encontrados neste trabalino. Os autores mostraram um aumento no valor do PER com a tostagem por 10 minutas seguido de um decréscimo nos 20 e 40 minutas, confirmando os nossos resultados. 0 tratamento de tostagem por longo períado causa um decréscimo na qualidade da proteina o que pode ser observado quando se faz uma comparação com o PER obtido da farinha de tremoço cru.

o tratamento de maceração em água dos grãos de tremoço por 3 dias, previamente cozidos por trinta minutos para obtenção de farinha, foi realizado por SCHOENEBERGER et alii (1982). Os autores avaliando a qualidade rutricional da proteina mostraram que o PER foi de 1,24 e o gantio de peso de 33 g, superiores aos resultados obtidos no presente trabalio, onde os grăos de tremoço sofreram maceraçăo por 3 dias. Porém, os autores năo utilizaram substâncias químicas durante o tratamento, podendo ser este o fator responsável pelos baixos valores encontrados no presente trabalino.

Os resultados obtidos para a Utilização L1quida da Proteina (NPU), apresentados na Figura 4, mostra que a nivel de $5 \%$ e $1 \%$ houve diferenças significativas entre 
as dietas $X I$ e as demais. A análise estatistica revelou também que a nivel de $5 \%$ as dietas I, II, III, IV, V, VII, VIII $e$ IX são significativamente diferentes das dietas VI, $X$ e XI, e a nivel de $1 \%$ houve diferença significtiva apenas para dieta de caselna (XI) em relação as demais. Esses resultados revelaram que o tratamento com agua destilada com $\mathrm{pH} \mathrm{2,0} \mathrm{foi} \mathrm{a} \mathrm{melhor} \mathrm{entre} \mathrm{os} \mathrm{outros} \mathrm{tratamentos} \mathrm{uma} \mathrm{vez}$ que promoveu uma maior utilização (retenção) da protelna, da farinha de tremoço, pelos animais. Embora o consumo de ração ou protelna, pelos animais que consumiram a dieta VI, tenha sido baixo como nas demais que continham farinha de tremoço, a sua utilizaçăo para o crescimento dos animais foi maior, quando comparados com as outras dietas elaboradas com farinha de tremoço.

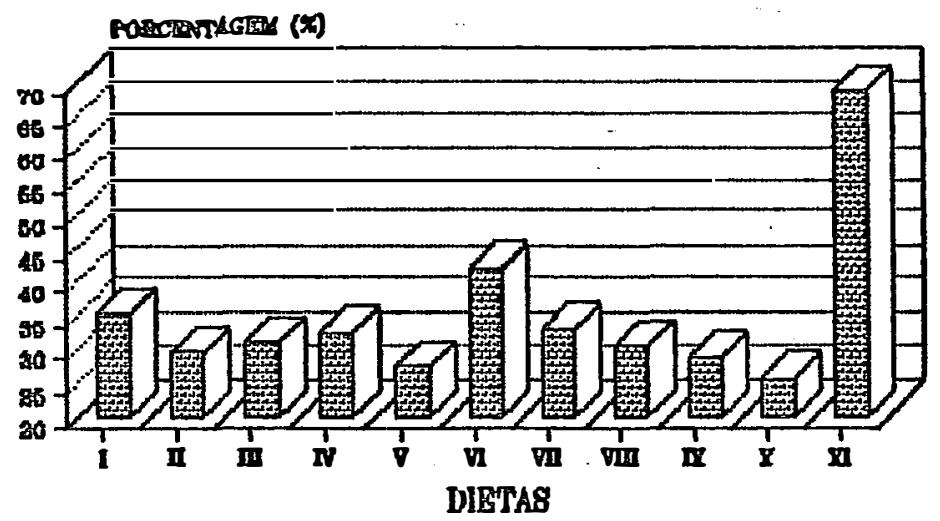

FARAVLR RPO

Figura 4. Valores da Utilização Líquida de Protelna (NPU), referente a cada dieta, duranteo $1^{\circ}$ ensaio biologico. 
A Figura 5, mostra os valores de digestibilidade obtidos no ensaio biológico. Os resultados indicaram que a nIvel de $5 \%$ e $1 \%$ a dieta XI (caselna) foi significativamente diferente em relação as demais dietas elaboradas com farinha de grãos de tremoço cru e submetidos a diferentes tratamentos. A analise estatistica revelou que a nIvel de $5 \%$, a digestibilidde foi maior para as dietas III $(86,51 \%)$ e IV $(86,83 \%)$ em relação as demais dietas feitas com os grãos de tremoço; e que o tratamento com metabissulfito de sódio reduziu significativamente a digestibilidade da dieta $X(81,80 \%)$ quando comparadas com as demais dietas do ensaio biológico. As dietas I, II, V, VI, VIII e $x$ não mostraram a nivel de 5\%, diferenças significativas entre $5 i$. Atraves desses resultados, observou-se que os tratamentos de tostagem durante 20 minutos (III) e 30 minutos (IV) promoveram efeitos satisfatórios sobre a digestibilidade da protelina dos grãos de tremoço, quando comparados com o tremoço cru $(84,07 \%)$, e portanto são superiores aos demais tratamentos efetuados nos referidos grãos.

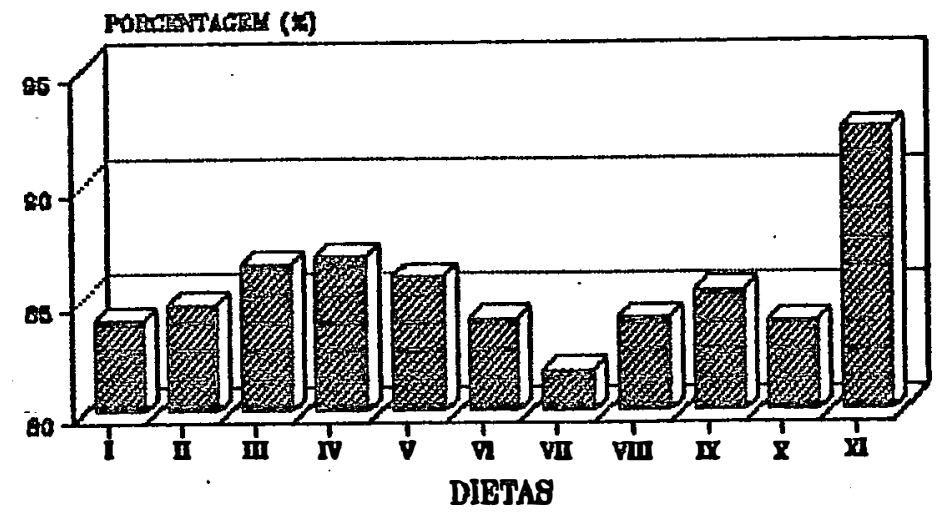

VERA VARAVR. D

Figura 5. Valores da Digestibilidade (D), referente a cada dieta, durante o 1 ensaio biológico. 
A Figura 6 mostra os resultados do Valor Biológico (VB), onde se verifica que a dieta XI apresentou diferenças significantes, a nivel de 5 e $1 \%$, em relação às demais dietas. O tratamento do grão de tremoço com água destilada - $\mathrm{pH} 2,0$, como mostra o valor biológico (50,06) foi superior a rível de $5 \%$ em relação ao tremoço cru e aos submetidos a outros tratamentos. As dietas IV e IX apresentaram valores menores para o $V B, 31,70$ e 30,44 , respectivamente, os quais mostraram diferenças significantes a nivel de $5 \%$ em relação às demais dietas. Os resultados da análise estatística também revelaram que à nível de $1 \%$, as dietas IV e IX não apresentaram diferenças significativas em relação às demais dietas elaboradas com grãos de tremoço submetidos a diferentes tratamentos.

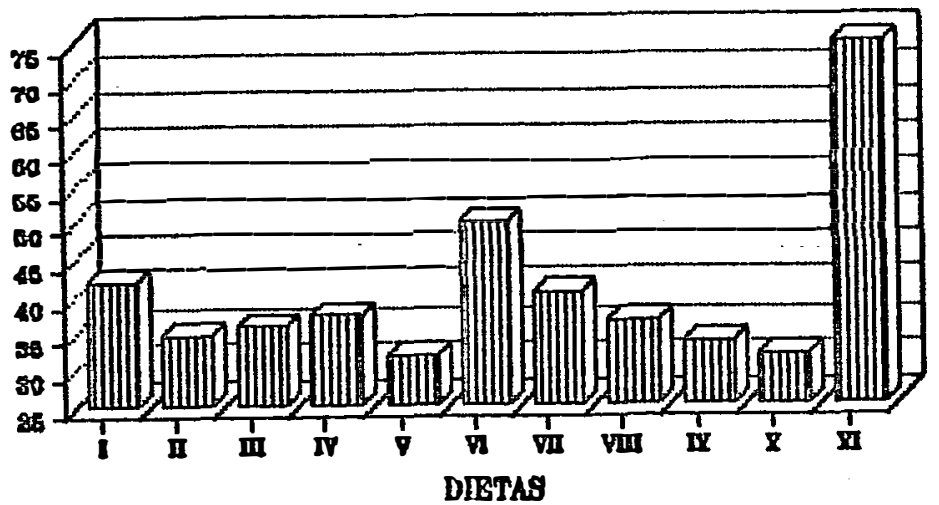

IIIII PARAVEL VB

Figura 6. Valores do Valor Biológico (VB), referente a cada dieta, durante o 1 o ensaio biológico. 
Através da análise estatística realizada com as variáveis estudadas no 1 o ensaio biológico, selecionou-se a farinha de grãos de tremoço obtida do tratamento com água destilada com pH 2,0 como a de melhor qualidade nutricional quando comparada com as farinhas obtidas dos demais tratamentos. A seleção foi realizada baseando-se nos dados obtidos do NPU $(42,00 \%)$ e VB $(50,06 \%)$ as quais fornecem, respectivamente a quantidade de protelna retida na carcaça, e a relação entre a quantidade de proteina retida na carcaça do animal e quantidade de proterna assimilada.

Embora, a análise estatística realizada no primeiro ensaio biológico tenha revelado que a farinha de grãos de tremoço tratados com metabissulfito de sódio foi a de pior qualidade nutricional, optou-se pela sua utilização na elaboração do "iogurte de tremoço" por não apresentar sabor amargo.

\section{3. 2. Segundo ensaio biológico}

$$
0 \text { segundo ensaio biológico visou a avaliação }
$$

da qualidade nutricional da protelna das farinhas de tremoço complementadas, considerando-se as mesmas variáveis estudadas no primeiro ensaio.

As porcentagens de.cada farinha, utilizadas no preparo da complementação ou misturas proteicas, foram 
obtidas através do cómputo químico teórico dos aminoácidos essenciais das mesmas comparados com o padrão da FAO $(1984)$

0 ganho médio de peso dos animais que consumiram as dietas complementadas está representada na figura 7. Os resultados foram analisados atraves do teste de Tukey, os quais mostraram que a nivel de 5 e $1 \%$, o gantio de peso dos animais que consumiram a dieta 9 (caselna) foi significativamente maior do que aqueles que consumiram as dietas complementadas.

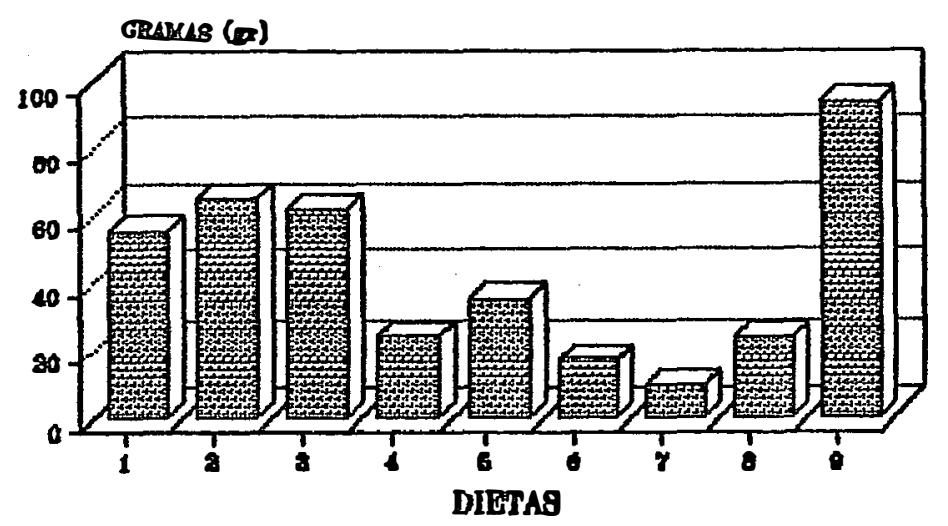

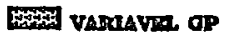

Figura 7. Ganho de peso dos animais, referente a cada dieta, durante o $2 \circ$ ensaio biológico. 
As dietas complementadas: trigo $(70 \%)+$ tremoço $(25 \%)+\operatorname{caupi}(5 \%)-1, \operatorname{trigo}(50 \%)+\operatorname{tremoço~}(35 \%)+$ caupi $(15 \%)$ - 2 e tremoşo $(70 \%)$ + semente de abóbora (30\%) 3, não apresentaram diferenças significativas entre si, mas superaram significtivamente em ganho de peso, comparando-se com os animais que consumiram as demais dietas complementadas. Os resultados de ganho de peso dos animais das dietas 6 (tremoço $60 \%+\operatorname{trigo~} 20 \%+\operatorname{milho}$ opaco-2 20\%) e 7 (tremoço $60 \%+$ ervilha $20 \%+$ trigo $20 \%$ ) revelaram que as mesmas, à nível de $5 \%$, não apresentaram diferenças significativas entre si, mas diferiram significativamente das demais. A nivel de $1 \%$ as dietas 4 (tremoço $50 \%+$ arroz $30 \%+$ caupi $20 \%$ ) e 8 (tremoço $50 \%+\operatorname{arroz} 30 \%+$ ervilha $20 \%$ ) não apresentaram diferenças significativas entre si, porém, diferiram das demais.

Em resumo, as dietas onde se constatou um maior ganho de peso entre os animais foram $1(64,23$ g), 2 $(61,43$ g) e $3(55,10$ g), as quais foram consideradas, para o ganho de peso, como as dietas que forneceram as melhores complementaçōes.

Os resultados ericontrados para as variáveis CEA e PER, mostrados respectivamente nas figuras 8 e 9 , foram semelhantes. 


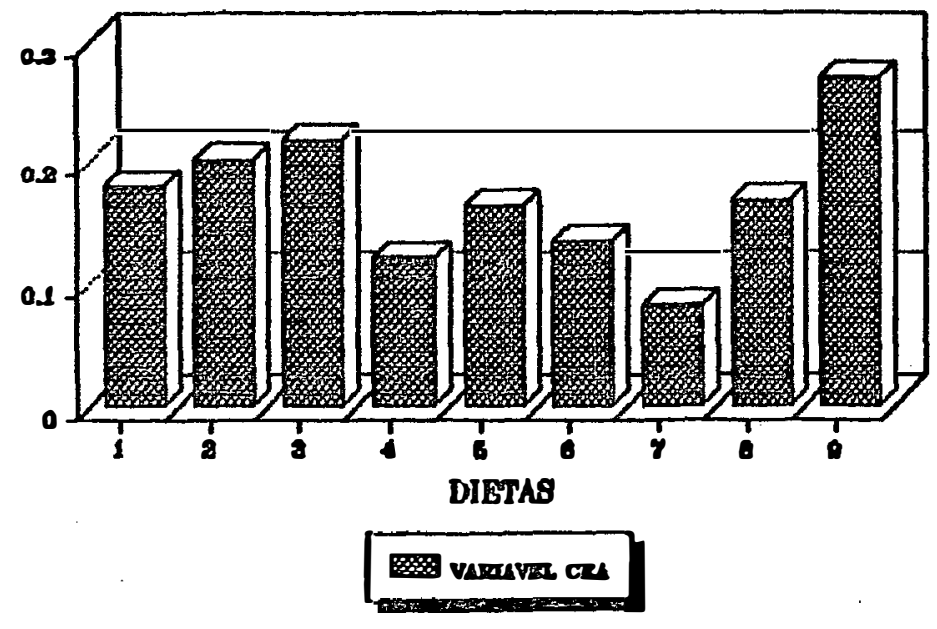

Figura 8. Valores do Coeficiente de Eficácia Alimentar (CEA), referente a cada dieta, durante 020 ensaio biológico.

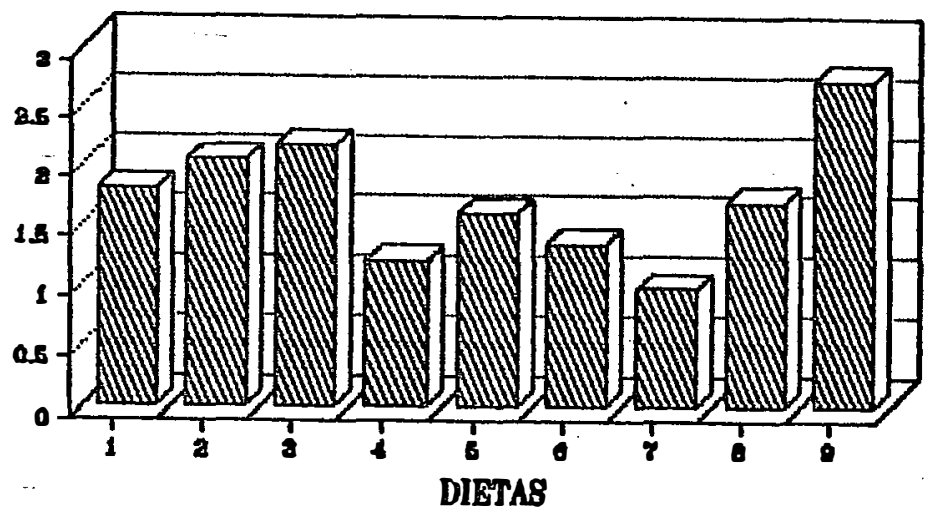

IIIII) VABZIAVA PBER

Figura 9. Valores da Taxa de Eficiência Proteica (PER), referente a cada dieta, durante o 2 e ensaio biologico. 
A análise estatistica para o CEA e PER revelou que a nivel de 5 e $1 \%$ a dieta 9 (caselna) apresentou valores significativamente superiores em relação à dietas complementadas. As dietas 3 complementada com $70 \%$ de tremoço + 30\% de semente de abóbora, 2 complementada com trigo $(50 \%)+\operatorname{tremoço~}(35 \%)+$ caupi $(15 \%)$ e 1 complementada com $\operatorname{trigo}(70 \%)+\operatorname{tremoço~}(25 \%)+\operatorname{caupi}(5 \%)$, não foram $5 i g n i-$ ficativamente diferentes a nivel de 5 e $1 \%$. No entanto, a dieta 3 mostrou diferenças significativas em relação as outras dietas complementadas.

Considerando-se ainda as variáveis CEA e PER, os resultados mostraram que as dietas 1 e 2 não apresentaram diferenças significativas com relação as dietas 5 (tremoço $50 \%+\operatorname{arroz} 30 \%+\operatorname{caupi} 20 \%$ ) e 8 (tremoço $50 \%$ + arroz $30 \%+$ ervilha $20 \%$ ). A dieta 6 (tremoço $50 \%+\operatorname{arroz} 30 \%+$ ervilha $20 \%$ ) mostrou-se significativamente superior as dietas 4 (tremoço 50\% + arroz 30\% + caupi 20\%) e 7 (tremoço $50 \%+\operatorname{arroz} 30 \%+$ ervilha $20 \%$ ).

A análise estatistica para CEA e PER mostrou que as complementaçăes das dietas 1,2 e 3 foram as melhores enquanto que as 4 e 7 foram considerads inferiores em relação às demais dietas complementadas.

Para o NPU mostrado na Figura 10, os resultados estatisticos indicaram que a dieta 9 (caselna) foi superior a todas as dietas complementadas. 


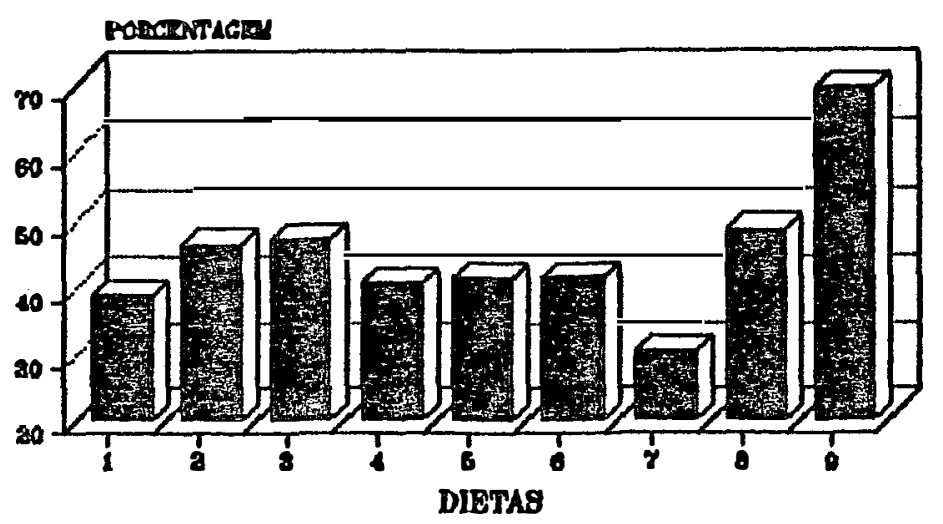

rime vamula NOPO

Figura 10. Valores da Utilização Liquida de Proteína (NPU), referente a cada cieta, durante 02 . ensaio biológico.

As dietas $1,2,3,4,5,6$ e 8, considerandose os resultados estatísticos para o NPU, não apresentaram diferenças significativas entre si. A dieta 7 apresentou o menor valor para o NPU $(30,38 \%)$, sendo considerada significativamente diferente das dietas $2,3,6$ e 8 . No entanto, a dieta 7 não mostrou diferenças significativa com relação as dietas 1,4 e 5 .

Esses resultados obtidos do NPU mostraram que as dietas 2, 3 e 8 foram as que apresentaram melhores complementaçơes, enquanto que a dieta.7 foi considerada a de pior qualidade nutricional.

Como mostra a Figura 11 , os resultados da Digestibilidade indicam que a dieta de caselna (9) foi significativamente superior com relação as demais dietas, considerando-se os niveis de 5 e $1 \%$ Os dados estatisticos 
também indicaram que as dietas $1,2,3,5,6$ e 8 apresentaram diferenças significativas em relação as dietas 4 e 7 , sendo consideradas as últimas, de menor qualidade, uma vez que apresentaram os manores valores de Digestibilidade. Os resultados da análise estatistica também mostraram que não houve diferenças significativas entre as dietas complementares 4,5 e 7 .

Dos resultados obtidos pode-se considerar que as dietas $1,2,3,6$ e 8 são as que apresentaram os melhores valores de Digestibilidade, ou seja, com menor porcentagem de perda de proteina pelas fezes.

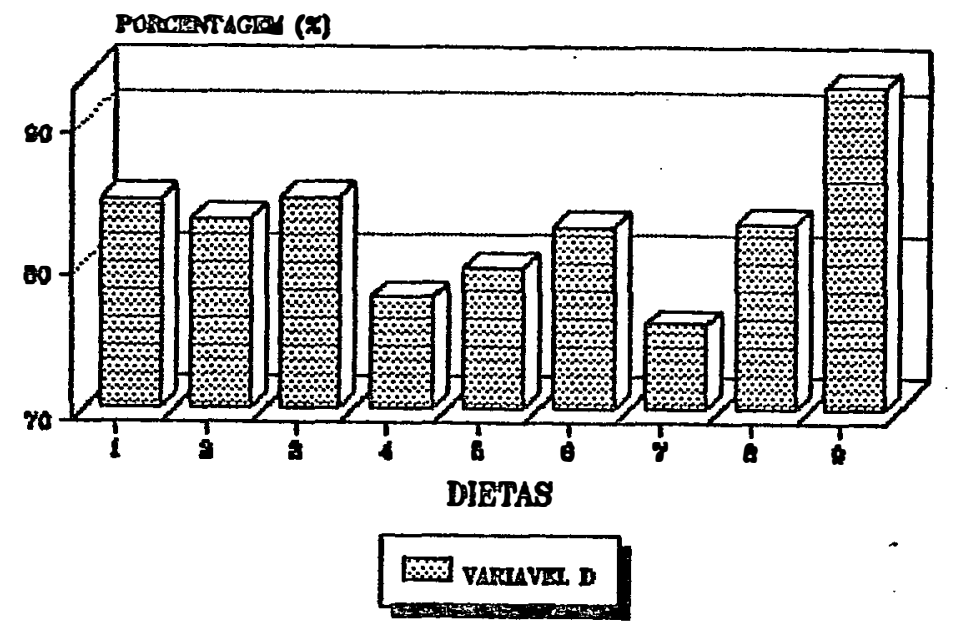

Figura 11. Valores da Digestibilidade (D), referente a cada dieta, durante 02 ensaio biológico. 
Os resultados encontrados para o Valor Biologico (VB) estão representados na Figura 12. A anălise estatistica dos dados obtidos revelaram que a dieta 9 foi superior em relação ds demais, considerando-se os niveis de significancia de 5 e $1 \%$ A nivel de $5 \%$ as dietas $2,3,4$, 5, 6 e 8 năo apresentaram diferenças significativas entre si. A dieta 1 apresentou diferença significativa com relaçăo à dieta 8, porém, năo foi considerada diferente das dietas 2, 3, 4, 5 e 7. A dieta 7 foi significativamente diferente das dietas 2, 3 e 8, porém năo diferiu das dietas 1, 4, 5 e 6. Os resultados estatísticos quanto ao Valor Biológico das proteinas estudadas, a nivel de $1 \%$, mostraram que as dietas 2, 3 e 8 não foram significativamente diferentes das dietas 1, 4, 5 e 6, porém diferiram da dieta 7. A dieta 7, entretanto, não foi significativamente diferente das dietas 1, 4, 5 e 6.

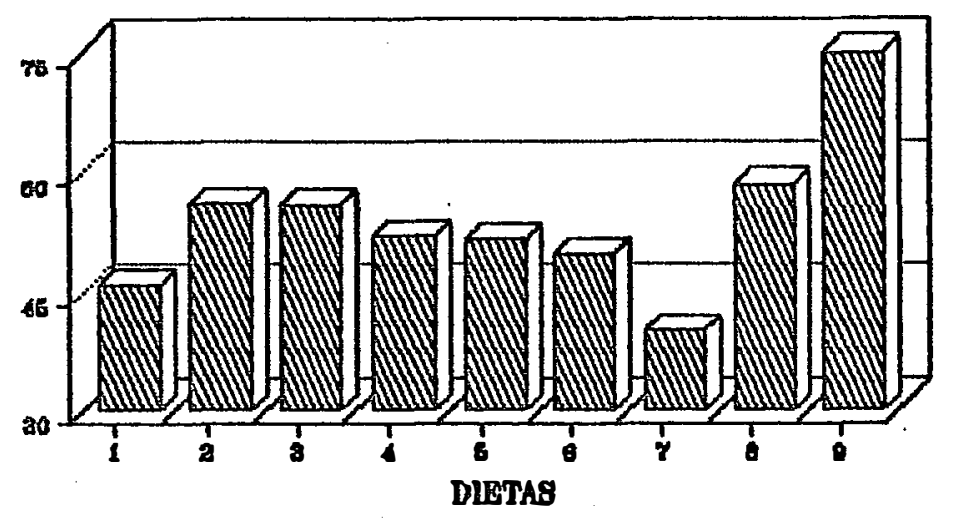

AIIV vagaveI vB

Figura 12. Valores do Valor Biológico (VB), referente a cada dieta, durante o 2 e ensaio biológico.- 
Quanto aos resultados obtidos da análise estatıstica, foi observado que a maioria das dietas complementadas apresentaram, de uma certa forma, algum grau de semelhança entre os dados coletados.' No entanto, analisando-se a Figura 12 observa-se que a dieta 8 foi a que apresentou médias mais altas, seguidas pela dieta 2 e 3.

Considerando-se todas as variáveis estudadas, foi constatado que as dietas 1,2 e 3 apresentaram as melhores complementaçð̋es embora os resultados diferem significativamente dos da dieta de caseina.

Os resultados obtidos do primeiro e segundo ensaio biológico não foram comparados estatisticamente, porém, a observação das figuras de cada ensaio mostra que a complementação das proteinas da farinha de tremoço com as farinhas de tirigo, arroz, ervilha, milho opaco-2, semente de abóbora e feijão caupi foi promissora do ponto de vista nutricional, uma vez que promoveu um maior consumo da dieta e consequentemente maior consumo de proteina, maior ganho de peso, maior aproveitamento da protelna e maior retenção da protelna na carcaça dos animais estudados.

O efeito promissor da complementação da proteina de tremoço, encontrados no presente trabalho, também foi estudado por BALLESTER et alii (1986), CATRICHEO et alii (1989) e CAMACHO et alii (1989). Esses autores relataram que a complementação da farinha de tremoço com a fa- 
rinha de outras fontes vegetais resulta em um produto cuja proteina apresenta um al to valor nutricional.

\section{4. Análises do extrato 1 lquido ("leite") e produto} fermentado ("iogurte")

0 volume do "leite de tremoço" extraldo de 2 quilogramas de grãos de tremoço seco foi de 4 litros. 0 conteúdo de sólidos totais obtidos de amostra de "leite" e "iogurte" de tremoço foi de 6,35 e 11,8\%, respectivamente.

0 "leite" de tremoço extraldo foi de coloração amarelo claro, com odor caracteristico. 0 tratamento térmico realizado em banho-maria $\left(70-80^{\circ} \mathrm{C}\right)$ durante $40 \mathrm{mi-}$ nutos promoveu uma redução no "flavor" de feijão, caracteristico da leguminosa estudada.

A introdução de leite desnatado e cultura lática no extrato, com posterior fermentação a $42 \circ \mathrm{C}$ por 8 horas, resultou em um produto com caracteristicas semelhantes ao iogurte natural. A coagulação das proteínas pelas bactérias láticas produziram uma textura cremosa firme, com aparência e odor agradáveis. 0 processo de fermentação resultou em um produto com acidez próxima a do iogurte natural. Os valores de pH obtidos para o iogurte natural e - "iogurte de tremoço" foram 4,4 e 4,1, respectivamente. 


\section{4.1. Análise bromatológica}

A Tabela 5 mostra a composição bromatológica do "leite" e "iogurte" obtidos com tremoço.

Tabela 5. Composição bromatológica do "leite" e "iogurte" de tremoço.

\begin{tabular}{|c|c|c|c|c|c|}
\hline Produtos & $\begin{array}{l}\text { Umidade } \\
\qquad(\%) *\end{array}$ & $\begin{array}{c}\text { Proteina } \\
(\%) *\end{array}$ & $\begin{array}{l}\text { Extrato } \\
\text { etereo } \\
(\%) *\end{array}$ & $\begin{array}{c}\text { Cinzas } \\
(\%) *\end{array}$ & $\begin{array}{l}\text { Fibra } \\
(\%) *\end{array}$ \\
\hline $\begin{array}{l}\text { "Leite de } \\
\text { tremoço" }\end{array}$ & 5,5 & 46,8 & 20,2 & 4,2 & 1,70 \\
\hline $\begin{array}{l}\text { "Iogurte } \\
\text { de tremoço" }\end{array}$ & 7,1 & 14,1 & 2,1 & 3,5 & 0,46 \\
\hline
\end{tabular}

* Valores médios de 3 repetiçöes.

0 "iogurte de tremoço" devido a quantidade de açúcares sofreu caramelização durante a secagem, o que pode ter influenciado na obtenção de teores inferiores de proteinas, no mesmo.

A quantidade de lactose foi analisada no "iogurte de tremoço", no iogurte natural e no "leite de tremoço" adicionados de $10 \%$ de leite em pó desnatado e $10 \%$ de iorgurte natural. Os resultados são apresentados na Tabela 6. 
Tabela 6. Conteúdo de lactose no "iogurte de tremoço", iogurte natural e "leite de tremoço" adicionado de $10 \%$ de leite em pó desnatado e 10\% de iogurte natural.

Produtos

Lactose

$(g / 100 \mathrm{ml})$

$\begin{array}{ll}\text { "Iogurte de tremoço" } & 0,50 \\ \text { "Iogurte natural" } & 1,25 \\ \text { "Leite de tremoço" + 10\% de } & \\ \text { leite em pó desnatado + 10\% } & \\ \text { de iogurte natural } & 0,75\end{array}$

0 "leite de tremoço" foi analisado quanto ao teor de carboidratos totais utilizando o método descrito por ABU-LEHIA (1987) para determinação de lactose em leite. método é sensível apenas para o leite, o qual contém na sua composição apenas lactose como carboidrato. 0 tremoço não contém lactose e sim outros açúcares, como: rafinose, estaquiose e varbascose (HILL, 1977). Sendo assim, a determinação de carboidratos no "leite de tremoço" nos possibilitaria, por diferença, a obtenção do conteúdo de lactose real presente no "iogurte de tremoço". No entanto o conteúdo de carboidratos em amostras do "leite de tremoço" foi muito baixo, não permitindo a sua determinação através do método empregado. Considerando-se que o "iogurte de tremoço" contém uma quantidade muito pequena de outros carboidratos, os resultados obtidos podem ser interpretados como a conteúdo de lactose total presente no produto. 
0 conteúdo de lactose $(1,25 \mathrm{~g} / 100 \mathrm{ml})$ no iogurte natural foi superior ao encontrado no "iogurte de tremoço" $(0,5 \mathrm{~g} / 100 \mathrm{ml})$. Os resultados indicaram que as bactérias láticas (iogurte natural) adicionadas no "leite de tremoço", para obtenção do iogurte, provavelmente utilizaram a lactose durante a fermentação.

0 "iogurte de tremoço", assim como o iogurte natural podem ser utilizados por individuos intolerantes à lactose, uma vez que, segundo GALLAGHER (1974) a utilização de leite fermentado com bactérias láticas e iorgurte eliminaram os sintomas de diarréia e a perda de cálcio pelas fezes em individuos com intoleråncia à lactose.

Dos resultados obtidos pode-se verificar que - "iogurte de tremoço" contém menor quantidade de lactose que o iogurte natural e possuem bactérias láticas, podendo ser utilizados como alimento alternativo, com caracteristicas desejáveis, para individuos intolerantes à lactose.

4. 4.2. Análise de minerais

A análise de minerais foi determinada nas amostras do extrato liquido de tremoço ou "leite de tremoço" e no produto fermentado com bactérias laticas ou "iogurte de tremoço". Os resultados săo apresentados na Tabela 7. 
Tabela 7. Conteúdo de minerais no "leite de tremoço" e "iogurte de tremoço".

\begin{tabular}{lcc}
\hline Minerais & $\begin{array}{c}\text { "Leite de } \\
\text { tremoço" }\end{array}$ & $\begin{array}{c}\text { Iogurte de } \\
\text { tremoço" }\end{array}$ \\
\hline$P(\%)$ & 0,12 & 0,51 \\
K $(\%)$ & 0,08 & 0,31 \\
Ca $(\%)$ & 0,03 & 0,19 \\
Mg (\%) & 0,05 & 0,03 \\
Cu (PPm) & 24,2 & 12,2 \\
Fe (pPm) & 118,0 & 34,0 \\
Mn (pPm) & 712,0 & 134,0 \\
Zn (PPm) & 193,0 & 73,0 \\
\hline
\end{tabular}

Como mostra a Tabela 7, encontrou-se no "iogurte de tremoço" quando comparados ao "leite de tremoço" niveis mais altos de cálcio, fósforo e potássio e uma redução nos teores de zinco, manganês, ferro, cobre e magnésio. Essa diferença no conteúdo de minerais nos dois produtos pode ter sido ocasionada pela adição de leite em pó, para elaboração do iogurte, o qual contém niveis elevados de cálcio $(1,08 \mathrm{mg} / \mathrm{g})$, fósforo $(0,82 \mathrm{mg} / \mathrm{g})$ e potássio $(1,7$ $\mathrm{mg} / \mathrm{g})$ e níveis baixos de zinco $(0,0046 \mathrm{mg} / \mathrm{g})$, manganês $(<0,0001 \mathrm{mg} / \mathrm{g})$, ferro $(0,00027 \mathrm{mg} / \mathrm{g})$ e cobre $(0,00005 \mathrm{~g} / \mathrm{mg})$ e mangésio $(0,092 \mathrm{mg} / g)$ (KRAUSE \& MAHAN, 1985), promovendo assim um acréscimo nos teores dos três primeiros minerais e uma diluição nos conteúdos dos últimos. 


\section{4. 3. Análise sensorial}

Tanto o "iogurte de tremoço" como o natural adicionados ou não de sabores de morango, abacaxi e chocolate foram analisados quanto à acidez, sabor, aroma, cor e textura. As classificaçช̃es dos produtos como ótimo, bom, regular e ruim foram obtidas das somas das notas dadas pelos provadores a todas as caracteristicas do produto. Os resultados obtidos nesta análise estão dispostos em porcentagens na Figura 13.

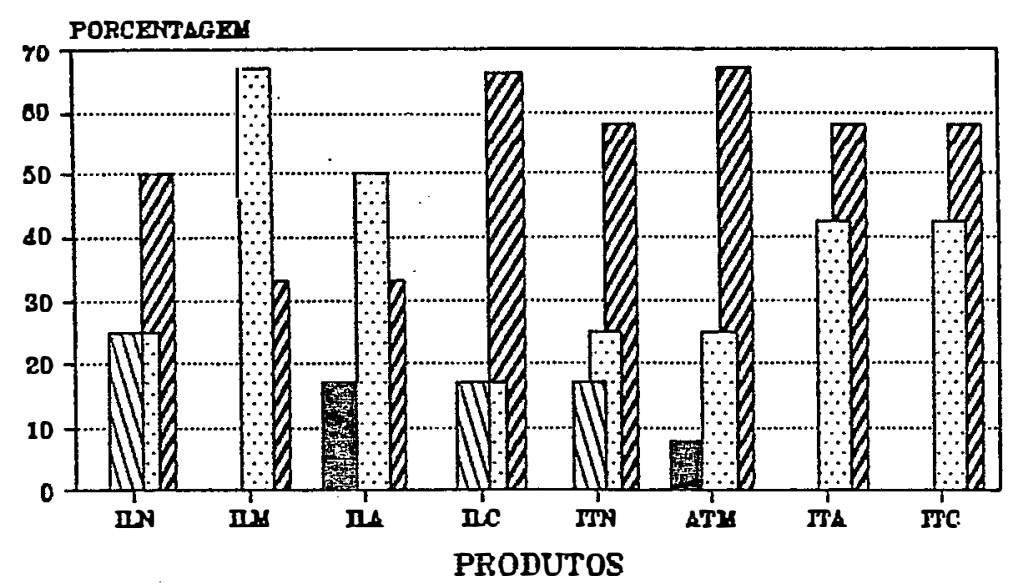

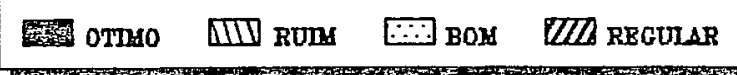

Figura 13. Classificação dos "iogurtes de tremoço" e iogurte natural (sem sabor e adicionados de sabores), quanto à acidez, sabor, aroma, cor e textura. 
Os dados coletados mostraram que o "iogurte de tremoço" natural ou seja sem adição de sabor, foi considerado regular por 58\% dos provadores e ruim por $17 \%$ deles, enquanto que para o iogurte natural 50\% dos degustadores classificaram-no como regular e $25 \%$ como ruim.

0 iogurte de leite adicionado de sabor morango foi considerado como bom por $67 \%$ dos provadores, enquanto que $67 \%$ classificaram o "iogurte de tremoço" como sabor morango, como regular. Quanto ao iogurte de leite com sabor abacaxi, 17\% acharam ótimo e 50\% bom. Já o iogurte de tremoço de abacaxi foi classificado como bom e regular por 42 e 58\% dos degustadores, respectivamente. 0s iogurtes de leite e tremoço adicionados de chocolate foram considerados bons por 17 e 42\%, e regular por 66 e $58 \%$, respectivamente.

A análise de preferéncia foi realizada com "iogurte de tremoça" natural, com sabores de morango, abacaxi e chocolate. Os resultados apresentados na Figura 14 mostram que 75\% dos degustadores gostaram do "iogurte de tremoço com sabor morango" e 58\% do iogurte de "tremoço com sabor abacaxi". Os "iogurtes de tremoço" sabor morango e sabor abacaxi, foram rejeitados por 17 e 8\% dos degustadores, respectivamente. 


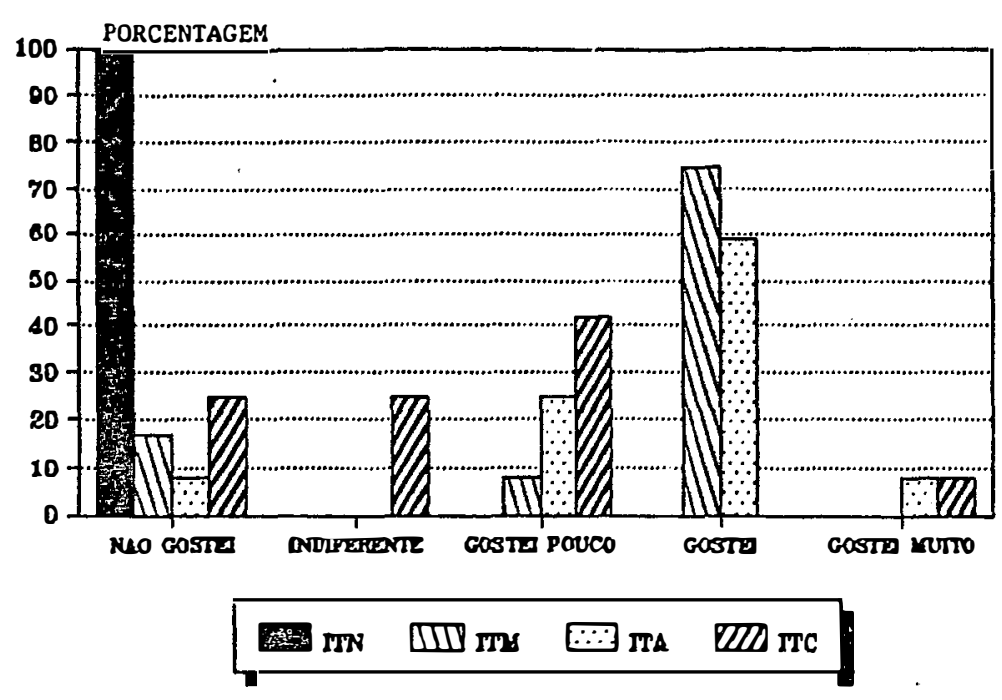

Figura 14. Classificação do "iogurte de tremoço" (sem sabor e adicionado de sabores), quanto ao grau de preferéncia. 


\section{CONCLUSÕES}

- A farinha obtida de grãos de tremoço tratados com água destilada $\mathrm{pH} 6,0$ foi a que apresentou melhores resultados do ponto de vista bromatológico.

- o tratamento dos grãos de tremoço com água destilada $\mathrm{pH} \mathrm{2,0} \mathrm{promoveu} \mathrm{a} \mathrm{obtenção} \mathrm{de} \mathrm{uma} \mathrm{farinha} \mathrm{com}$ melhor valor nutricional.

- A farinha de tremoço tratada com metabissulfiti de sódio foi considerada, nutricionalmente, inferior às outras, porém não apresentou sabor amargo, 0 que a caracteriza como a melhor, quando se considera a qualidade organoléptica da farinha.

- As farinhas complementadas de maior valor nutricional foram as farinhas de trigo $(70 \%)+$ tremoço $(25 \%)+$ feijăo caupi $(5 \%), \operatorname{trigo}(50 \%)+\operatorname{tremoço~}(35 \%)+$ feijăo caupi $(15 \%)$ e de tremoço $(70 \%)$ + semente de abóbora $(30 \%)$ 
- 0 iogurte elaborado com grãos de tremoço apresentou caracteristicas organolepticas desejáveis e boa aceitabilidade.

- 0 conteúdo de lactose presente no "iogurte de tremoço" foi menor do que no iogurte natural, podendo ser consumido por pacientes intolerantes à lactose.

- 0 "iogurte de tremoço" sabor morango apresentou maior preferencia entre os degustadores. 


\section{REFEREENCIAS BIBLIOGRÁFICAS}

ABU-LEHIA, I.H. A simple and rapid colorimetric method for lactose determination in milk. Food Chemistry, England, 24: $233-40,1987$.

AGOSIN, E.; DIAZ, D.; ARAVENA, R.; YASEZ, E. Chemical and nutritional characterization of lupine tempeh. Journal of Food Science, Chicago, 5(1): 102-4, jan/febr, 1989.

ASSOCIATION OFFICIAL ANALYTICAL CHEMISTS. Official methods of analysis, 14 ed. Arlington, 1981. $1141 \mathrm{P}$.

AGUILERA, J.M. The revival of the Lupin. Food Technology, Chicago, $32(8): 70-5,1978$.

BAllester, D.; YÃAez, E.; GARCiA, R., ERAZO, S.; LOPEZ, F.; HAARDT, E.; CORNEJO, S.; LOPEZ, A., POKNIAK, J.; CHICESTER, C.0. Chemical composition, value nutritive, and toxicological evaluation of two species of sweet lupine (Lupinus albus and Lupinus luteus). Journal of Agricultural and Food Chemistry, Washington, 28: 402-5, 1980. 
BALLESTER, D.; ZACARIAS, I.; GARCIA, E.; YAAEZ, Z . Baking studies with full-fat sweet lupine fluor ( $L$. albus cV. Multolupa). Journal of Food Science, Chicago, 40: 14-7, 1984 .

BALLESTERM D.; CARREAO, P.; URRUTIA, X.; YAAEZ, E. Chemical composition and nutritional quality of sugar cookies containying full - fat sweet Lupie flour ( $L$. albus cV. Moltolupa). Journal of Food Science, Chicago, $51(3)$ : 645-7, may-june, 1986.

BENASSI, A.C. Efeitos da época de semeadura, espaçamento e momentos de corte no desenvolvimento, produção e massa verde, matéria seca e sementes de tremoço (Lupinus albus L.). Piracicaba, 1988. 155p. (Mestrado - Escola Superior de Agricultura "Luiz de Queiroz"/USP).

CAMACHO, L.; BAAAADR, E.; FERNÁNDEZ, E. Enlatado de "humitas" preparadas com maiz opaca-2 complementado com lupino dulce (Lupinus albus var. Multolupa). Cambios nutricionales y de calidad. Archivos Latinoamericanos de $\mathrm{Nu}-$ tricion, Guatemala, 39(2): 185-99, jun. 1989

CAMPOS, J.E. \& EL-DASH, A.A. Effect of addition of full-fat sweet lupine flour en rheological properties of dough and baking quality of bread. Cereal Chemistry, St. Paul, 55 (5): $619-27,1978$.

CATAPAN, M.I.S.; NUTES, R.M.R.; BATER, A.C. Herança da cor da flor e da quilha, do teor de alcalóide dos ciclos em tremoço (Lupinus SPP.). Ciência e Cultura, São Paulo, 40 $(12)$ : $1131-4$, dez. 1984. 
CATRICHEO, R.; SANCHEZ, F.; AGUAYO, M.; BALLESTER, DN; YAAEZ, E. Desarrollo y evaluacion quimica y nutricional de un alimento infantil a base de Lupino dulce, trigo y leche. Archivos Latinoamericano de Nutricion, Guatemala, $39(2): 144-9$, jun. 1989.

CERNING, B. \& FILTATRE, A. A comparison of the carbohydrate composition of Legume seeds: horsebeans, pea and Lupine. Cereal Chemistry, St. Paul, 53(6): 968-78, 1976.

CONTRERAS, S.; ARAYA, H.; PAK, N.; TAGLLE, M.A. Factores tóxicos de leguminosas cultivadas em Chile I. Glucosideos cianogénicos. Archivos Latinoamericano de Nutricion, Guatemala, 23: 251-9, 1973.

CONTRERAS, S. \& TAGLLE, M.A. Factores tóxicos. de leguminosas cultivadas en Chile. I I . Hemaglutiminas. Archivos Latinoamericano de Nutricion, Guatemala, 24(2):1991-9, jun. 1974 .

DREYER, J.J. Dietary protein supplementation, fundamentals and examples of practical application. Archivos Latinoamericano de Nutricion, Guatemala, 36(4): 101-13, nov. 1986.

EL-DASH, A.A. \& SGARBIERI, V.C. Sweet Lupine - fortfied bread: Nutricional value and amino acid content. Cereal Chemistry, St. Paul, 57(1): 9-11, 1980.

FAO, Aminoacido scoring pattern, Rome, 1984,. 173p.

Floss, E.L. A cultura do tremoço. Lavoura Arrozeira, Porto Alegre; $33(323): 46-50,1980$. 
GALLAGUER, C.H.R. Lactose intolerance fermented dairy products. Journal dietetic Association, London, 65: 4189, 1974 .

GOMES, F.P. Curso de Estatistica Experimental . Piracicaba, Nobel, 1987. 467p.

GRISWOLD, R.M. Estudo Experimentos dos Alimentos. Săo Pau10, Edgard Blucher, 1972. 469p.

GROSS, R. \& VON-BAER, E. Possibilidades de Lupinus mutabilis Y Lupinus albus in los paises andinos. Archivos Latinoamericano de Nutricion, Guatemala, 27: 451-72, 1977 .

GUILlaume, J.; CHENIEUX, J.C.; RIDEUA, M. Feeding value of Lupinus albus in chicken diets (with emphasis on the role of alkaloids). Nutrition Report Internation, Staneham, $20((1)$ : 59-65, jully, 1979 .

HILL, G.D. The composition and nutritive value of lupin seed. Nutrition Abstracts Reviews, Series B, 47: 511-29, 1977.

HUNG, T.V.; HANDSON, D.; AMENTA, V.C.; KYLE, W.S.A.; YU, R.S.T. Content and distribution on of manganese in Lupin seed grow in Victoria and Lupin flour, spray-dried powder and protein isolate prepared from the seed. Journal of the Science of Food and Agriculture, 0xford, 45: $145-54,1988$.

HUNG, T.V.; HANDSON, P.D.; AMENTA, V.C.; KYLE, W.S.A.; YU, R.S.T. Mineral composition and distribution in Lupin seeds and in flour spray dried. powder and protein isolate produced from the seeds. Journal of the Science of Food and Agriculture, Oxford, 45: 145-54, 1988. 
JIJIBA, C.L. \& BRESSANI, G. Evaluacion de la calidad proteinica de harinas de leguminosas obtenidas por tostacion in lechos calentados. Archivos Latinoamericano de Nutricion, Guatemala, 1: 152-61, mar. 1988.

KRAUSE, M.V. \& MAHAN, L.K. Alimentos, Nutrição e Dietoterapia. São Paulo, Roca, 1985. 1052p.

KIM, C.S. \& MADHUSUDHAN, K.T. Haemagglutinating and trypsin inhibitor activities of lupin seed (Lupinus angustifolius). Journal of Food Science, Champaign, 53(4): 12355,1988 .

LAGO, E.S.; BION, F.M.; COSTA, L.P. da. Valor biológico das protelnas do feijăo macaçar complementado com aminoácidos. Revista Brasileira de Pesquisa Médica e Biológica, Ribeirão Preto, 4: 343-50, 1971 .

MORAES, M.A.C. Metodos para avaliaçăo sensorial de alimentos. 3 ed. Campinas, Fundação Tropical de Pesquisas e Tecnologia, 1981. 62p.

MúzQUIZ, M.; BURBANO, C.; GOROSPE, M.J.; RÓDENAS, I.A. Chemical study of Lupinus hispanicus seed-toxic antinutritional components. Journal of the Science of Food and Agriculture, Oxford, 47: 205-14, 1989.

OKAKA, J.C. \& POTTER, N.N. Function and storage properties of cowpea powder- wheat flour blends in breadmaking. Journal of Food Science, Chicago, 42(3): 828-33, 1977.

OKAKA, J.C. \& POTTER, N.N. Physicochemical and functional properties of cowpea powders processed to reduce beany flavor. Journal of Food Science, Chicago, 44: 1236-40, 1979 . 
OOMAH, B.D. \& BUSHUK, W. Characterization of Lupin Proteins. Journal of Food Science, Chicago, 48: 38-41, 1983.

PENNA, E.W. de; CARREAo, P.; LOPEZ, L.; URRUtTA, X.; BallesTER, D. Sensory Evaluation and Acceptability of Cookies Enriched with sweet lupin flours (Lupinus albus cv. Multolupa). Journal of Food Science, Chicago, 52(5): 1434$5,1987$.

PENNA, E.W. de, CAstro, X.; CERDA, P.; SAllesssper, D. Evaluacion de la calidad sensorial y la aceptabilidad de pan corriente (tipos "Hallula" y "Marraqueta") enriquecido con harina de lupido dulce (Lupinus albus, var. Multolupa). Revista de Agroquimica y Tecnologia de Alimentos, Valéncia, 28(1): 127-35, 1988.

PINTHONG, R.; MACRAE, R.; ROTHWELL, J. The development of a soya-basead yoghurt II. Sensory evaluation and analysis of volatiles. Journal Food Technology, London, 15: 6539, 1988 .

RAHMA, E.H. \& NARASINGA RAO, M.S. Effect of Debiterring Treatment on the Composition and Protein Components of Lupin Seed (Lupinus termis) flour. Journal Agriculture Food Chemistry, Washington, 32: 1026-30, 1984.

SAINI, H.S. \& GLASTONES, J.S. Variability in the total and component galactosyl sucrose Oligosaccharides of Lupinus species. Australian Journal Agricultural Research, Sourth Perth, 37: 157-66, 1986.

SALES, M.G. Characteristics of processed food from whole cowpeas (Vigna sinensis). Arizona, 1980. 142p. (Doutorado - University of Arizona). 
SANTOS, H.P. dOS; LHAMBY, J.C.B.; TOMASINI, R.G.A.; BATER, A.C. Pesquisas Desenvolvidas com o Tremoço (Lupinus spp) em Passo Fundo no Período de 1980 a 1983. Passo Fundo, EMBRAPA-CNPT, 1984.

SARRUGE, J.R. \& HAAG, H.P. Análises Químicas em Plantas. Piracicaba, 1974. 56p.

SCHERER, E.E. O tremoço e seu cultivo no Estado de Santa Catarina. Florianópolis, EMPASC, 1982. 20p. (EMPASC, Boletim Técnico, 14).

SCHOENEBERGER, H.; GROSS, R.,; CREMER, H.D.; ELMADFA, I. The protein quality of water debittered lupines (Lupinus mutabilis) in combination with other protein sources. Nutrition Reports International, Stoneham, 25(5): 763-71, may 1982 .

SGARBIERI, W.C.C \& GALEAZZI, M.A.M. Some physicochemical and nutrition properties of a sweet lupin (Lupinus albus var. Multolupa) protein. Journal Agriculture Food Chemistry, Wastington, 26(6): 1438-42, 1978.

TAHA, F.S. \& EL-NOCKERASHY, A.S. Unconventional protein sources. I. Lupinus albus. Agricultural Biological Chemistry, Tokyo, 46(1): 2625-9, 1982.

TRUGO, L.C.; ALMEIDA, D.C.F.; GROSS, R. Oligosaccharide contents in the seeds of cultivared lupins. Journal of The Food Science of Food and Agriculture, 0xford, 45: $21-4,1988$.

UFER, M. de. 0 lupino (tremoço) branco doce. Seu cultivo e seu valor. Granja, Brasil, 12: 81, 1956. 
VASQUEZ, M.; KNAPP, E.; GUZMAN, E.; ZACARIAS, I. Protelmas de lupino dulce (Lupinus luteus var. Aurea/Welco, y Lupinus albus var. Multolupa). I. Extraccion y filtracion por sephadex. Archivos Latinoamericano de Nutricion, Guatemala, 34(2): 150-7, 1989.

WORLD HEALTH ORGANIZATION. Internacional Standards for Drinking Water, 3 ed., 1971. $81 \mathrm{p}$.

YATEZ, E.; LOBOS, P.; DIAZ, G.; BALLESTER, D. Effect of roasting on the chemical composition and protein quality of lupin seeds (Lupinus albus cV. Multolupa). Journal of Food Science, Chicago, $51(5)$ : 1235-8, 1986.

ZACARIAS, I.; YASEZ, E.; ARAYA, E.; BALLESTER, D. Evaluacion Sensorial y Estudio de Aceptabilidad, a nivel de Consumidor, de Pan Suplementado con Harina de Lupino Dulce. Archivos Latinoamericanos de Nutricion, Guatemala, 35(1): 119-29, mar. 1985. 


\section{A P E $N$ D I CE}


FORMULARIO PARA ANALISE SENSORIAL

Provador:

Data: '

Produto:

No balçăo estăo dispostos 8 amostras de iogurte. Por favor, gostaríamos que vocé as julgasse quanto ácidez, sabor, aroma, cor e textura seguindo a classificaçăo:

\begin{tabular}{|c|c|c|c|c|c|}
\hline Amostras & Acidez & Sabor & Aroma & Cor & Textura \\
\hline$\ldots \ldots$ & $\ldots \ldots$ & $\ldots \ldots$ & $\ldots \ldots$ & $\ldots$ & $\ldots \ldots$ \\
\hline$\ldots \ldots$ & $\ldots \ldots$ & $\ldots \ldots$ & $\ldots \ldots$ & $\ldots$ & $\ldots \ldots$ \\
\hline$\ldots \ldots$ & $\ldots \ldots$ & $\ldots \ldots$ & $\ldots \ldots$ & $\cdots$ & $\ldots \ldots$ \\
\hline$\ldots \ldots$ & $\ldots \ldots$ & $\ldots \ldots$ & $\ldots \ldots$ & $\ldots$ & $\ldots \ldots$ \\
\hline$\ldots \ldots$ & $\ldots \ldots$ & $\ldots \ldots$ & $\ldots \ldots$ & $\ldots$ & $\ldots \ldots$ \\
\hline$\ldots \ldots$ & $\ldots \ldots$ & $\ldots \ldots$ & $\ldots \ldots$ & $\cdots$ & $\cdots$ \\
\hline$\ldots \ldots$ & $\ldots \ldots$ & $\ldots$ & $\ldots \ldots$ & $\ldots$ & $\ldots \ldots$ \\
\hline$\cdots$ & $\ldots \ldots$ & $\ldots \ldots$ & $\ldots$ & $\ldots$ & - \\
\hline
\end{tabular}

\section{Classificação:}

Ácidez: năo ácido (NA), moderadamente ácido (MA), ácido (A), muito ácido (MLA

Sabor: ruim (R), regular (RE), bom (B), muito bom (MB), ótimo (D).

Aroma: indiferente (I), pouco agradável (PA), agradável (A), muito agradável (MA).

Cor: indiferente (I), pouco agradável (PA), agradável (A), muito agradável (MA).

Textura: liquida (L), pouco cremosa (PC), cremosa (C), pastosa (P), muito pastosa (MP). 


\section{PREFERENCIA}

Prove as amostra e indique, com números sua preferência pelo produto.

$\begin{array}{lll}\text { Anostras } & \text { Notas } & \text { (1) Năo gostei } \\ \ldots \ldots \ldots & \ldots \ldots & \text { (2) Indiferente } \\ \ldots \ldots \ldots & \ldots \ldots & \text { (13) Gostei pouco } \\ \ldots \ldots \ldots & \ldots \ldots & \text { (4) Gostei } \\ \ldots . . . & \ldots . . & \text { (5) Gostei muito }\end{array}$

OBSERVAÇZES: 
ANÁLISE ESTATISTICA DO 10. ENSAIO BIOLGGICO

Quadro n॰ 1 - Anḱlise de variância para os dados obtidos do ganto de peso.

\begin{tabular}{lccccc}
\hline C.V. & G.L. & S.Q. & Q.M. & VALOR F & PROB. SF \\
\hline TRATAMEN & 10 & $\begin{array}{r}39218.5582893 \\
1926.1854501\end{array}$ & $\begin{array}{r}3921.8558289 \\
35.0215536\end{array}$ & 111.9841 & 0.00001 \\
RESI DUO & 55 & & & \\
\hline TOTAL & 65 & 41144.7437393 & & \\
\hline
\end{tabular}

MEDIA GERAL $=16.880302$

COEFICIENTE DE VARIAÇÃO $=35.058 \%$

Quadro $n^{\circ} 2$ - Resultados da aplicação do teste de Tukey para as médias de tratamentos da variável ganho de peso.

\begin{tabular}{|c|c|c|c|c|}
\hline NUM. TRAT. & NOME & MÉDIAS & $5 \%$ & $1 \%$ \\
\hline $11-$ & CASE & 93.366669 & $a$ & $A$ \\
\hline $1-$ & STRA & 14.083332 & $b$ & B \\
\hline 2 & T1OM & 11.383334 & $b c$ & B \\
\hline 5 & T4OM & 10.866667 & bc & B \\
\hline 6 & PHD & 10.616666 & $b c$ & B \\
\hline 7 & $\mathrm{PH4}$ & 9.833333 & bc & B \\
\hline 4 & TSOM & 9.100000 & bc & $\mathrm{B}$ \\
\hline 8 & PHS & 8.933533 & bc & $\mathrm{B}$ \\
\hline 9 & BICA & 8.216667 & $b c$ & B \\
\hline 3 & T2OM & 8.166667 & bc & $\mathrm{B}$ \\
\hline 10 & MESO & 1.116667 & c & B \\
\hline
\end{tabular}

Médias seguidas por letras distintas diferem entre $s i$ ao nível de significåncia indicado:
D.M.S. $5 \%=$
11.48191
D.M.S. $1 \%=$
13.45697 
Quadro n॰3 - Análise de variåncia para os dados obtidos do CEA.

\begin{tabular}{lccccc}
\hline C.V. & G.L. & S.Q. & Q.M. & VALQR F & PROB. $>F$ \\
\hline TRATAMEN & 10 & 0.2503454 & 0.0250345 & 29.2646 & 0.00001 \\
RESI DUO & 55 & 0.0470500 & 0.0000556 & & \\
\hline TOTAL & 65 & 0.2973954 & & \\
\hline MEDIA GERAL $=$ & 0.085909 & & \\
COEFICIENTE DE VARIAÇ.ZTO $=34.045 \%$
\end{tabular}

Quadro n॰4 - Resultados da aplicação do teste de Tukey para as médias de tratamentos da variável CEA.

\begin{tabular}{|c|c|c|c|c|}
\hline NUM. TRAT. & NOME & MÉDIAS & $5 \%$ & $1 \%$ \\
\hline 11 & CASE & 0.270000 & $a$ & $A$ \\
\hline 1 & STRA & 0.088333 & $b$ & $\mathrm{~B}$ \\
\hline 2 & T1OM & 0.085000 & $b$ & $\mathrm{~B}$ \\
\hline 7 & $\mathrm{PH} 4$ & 0.078353 & $b$ & $\mathrm{~B}$ \\
\hline 4 & T3OM & 0.007833 & $b$ & $\mathrm{~B}$ \\
\hline 5 & TAOM & 0.075000 & $b$ & $\mathrm{BC}$ \\
\hline 6 & PH2 & 0.070000 & $b$ & $\mathrm{BC}$ \\
\hline 8 & PHS & 0.068353 & $b$ & $\mathrm{BC}$ \\
\hline 3 & T2OM & 0.063333 & bc & $\mathrm{BC}$ \\
\hline 9 & BICA & 0.058333 & be & $\mathrm{BC}$ \\
\hline 10 & MESO & 0.010000 & C & C \\
\hline
\end{tabular}

Medias seguidas por letras distintas diferem entre si ao nível de significância indicado:
D.M.S. $5 \%=$
0.05675
$-$
D.M.S. $1 \%=$
0.06651 
Quadro n॰5 - Análise de variåncia para os dados obtidos do PER.

\begin{tabular}{|c|c|c|c|c|c|}
\hline C.V. & G.L. & S.Q. & Q.M. & VALOR F & PROB. >F \\
\hline $\begin{array}{l}\text { TRATAMEN } \\
\text { RESI DUO }\end{array}$ & $\begin{array}{l}10 \\
55\end{array}$ & $\begin{array}{r}25.4495700 \\
5.0221829\end{array}$ & $\begin{array}{l}2.5449570 \\
0.0913124\end{array}$ & 27.8709 & 0.00001 \\
\hline TOTAL & 65 & 30.4717529 & & & \\
\hline MED I A GEF & $=$ & 0.862879 & & & \\
\hline
\end{tabular}

Guadro n०6 - Resultados da aplicação do teste de Tukey para as médias de tratamentos da variável PER.

\begin{tabular}{|c|c|c|c|c|}
\hline NUM. TRAT. & NOME & MÉdIAS & $5 \%$ & $1 \%$ \\
\hline 11 & CASE & 2.723333 & $a$ & $A$ \\
\hline 1 & STRA & 0.903353 & b & B \\
\hline 2 & T1OM & 0.851667 & b & $B$ \\
\hline 7 & $\mathrm{PH} 4$ & 0.788353 & b & $\mathrm{BC}$ \\
\hline 5 & T4OM & 0.768353 & b & $\mathrm{BC}$ \\
\hline 6 & PHR & 0.718333 & $b$ & $\mathrm{BC}$ \\
\hline 8 & PHS & 0.708353 & b & $\mathrm{BC}$ \\
\hline 4 & TSOM & 0.691667 & bc & $\mathrm{BC}$ \\
\hline 3 & T2OM & 0.636667 & bc & $\mathrm{BC}$ \\
\hline 9 & BICA & 0.590000 & bc & $\mathrm{BC}$ \\
\hline 10 & MESO & 0.111667 & c & C \\
\hline
\end{tabular}

Médias seguidas por letras distintas diferem entre $s i$ ao ní vel de significância indicado:
D.M.S. $5 \%=$
0.58629
$-$
D.M.S. $1 \%=$
0.68714 
Quadro n०7 - Análise de variåncia para os dados obtidos do NPU.

\begin{tabular}{|c|c|c|c|c|c|}
\hline C.V. & G.L. & S.Q. & Q.M. & VALOR F & $\mathrm{PaOB} .>\mathrm{F}$ \\
\hline $\begin{array}{l}\text { TRATAMEN } \\
\text { RESI DUO }\end{array}$ & $\begin{array}{l}10 \\
55\end{array}$ & $\begin{array}{l}8873.5762944 \\
3253.6663320\end{array}$ & $\begin{array}{r}887.3576294 \\
59.1575697\end{array}$ & 14.9999 & 0.00001 \\
\hline TOTAL & 65 & 12127.2426264 & & & \\
\hline MEDIA GER & $A_{L}=$ & 34.896515 & & & \\
\hline
\end{tabular}

Quadro n॰8 - Resultados da aplicação do teste de Tukey para as médias de tratamentos da variável NPU.

\begin{tabular}{|c|c|c|c|c|}
\hline NUM.TRAT. & NOME & MÉDIAS & $5 \%$ & $1 \%$ \\
\hline 11 & CASE & 69.064992 & $a$ & $A$ \\
\hline 6 & $\mathrm{PH} 2$ & 42.003334 & $\mathrm{~b}$ & $\mathrm{~B}$ \\
\hline 1 & STRA & 35.213553 & $b c$ & $\mathrm{~B}$ \\
\hline 7 & PH4 & 32.941666 & $b c$ & $\mathrm{~B}$ \\
\hline 4 & T3OM & 32.440000 & $b c$ & $\mathrm{~B}$ \\
\hline 3 & T2OM & 30.930000 & bec & $\mathrm{B}$ \\
\hline 8 & PHS & 30.448331 & be & $\mathrm{B}$ \\
\hline 2 & T1OM & 29.299998 & $b c$ & $\mathrm{~B}$ \\
\hline 9 & BICA & 28.733332 & $b c$ & $\mathrm{~B}$ \\
\hline 5 & T4OM & 27.273331 & $b c$ & B \\
\hline 10 & MESO & 25.513334 & c & $\mathrm{B}$ \\
\hline
\end{tabular}

Médias seguidas por letras distintas diferem entre si ao ní vel de significância indicado:
D.M.S. $5 \%=$
14.92285
$-$
D.M.S. $1 \%=$
17.48980 
Quadro n०9 - Análise de variåncia para os dados obtidos da D.

\begin{tabular}{lrrrrr}
\hline C.V. & G.L. & S.Q. & Q.M. & VALOR F & PaOB.>F \\
\hline TRATAMEN & 10 & 433.7157035 & 43.3715703 & 7.3960 & 0.00001 \\
RESI DUD & 55 & 322.5291571 & 5.8641665 & & \\
\hline TOTAL & 65 & 756.2448606 & & & \\
\hline
\end{tabular}

MEDIA GERAL $=85.447121$

COEFICIENTE DE VARIAÇ.̃OO = $2.834 \%$

Quadro n॰10 - Resultados da aplicaçăo do teste de Tukey para as médias de tratamentos da variável $\mathrm{D}$.

\begin{tabular}{|c|c|c|c|c|}
\hline NUM. TRAT. & NOME & MÉDIAS & $5 \%$ & $1 \%$ \\
\hline 11 & CASE & 92.360006 & $a$ & $A$ \\
\hline 4 & T3OM & 86.836670 & $b$ & B \\
\hline 3 & T2OM & 86.516663 & $b$ & B \\
\hline 5 & T4OM & 85.961670 & $b c$ & B \\
\hline 9 & BICA & 85.338338 & $b c$ & $\mathrm{~B}$ \\
\hline 2 & T1OM & 84.740000 & $b c$ & B \\
\hline 8 & PHS & 84.191671 & be & $\mathrm{B}$ \\
\hline 6 & PHC & 84.098338 & $b c$ & $\mathrm{~B}$ \\
\hline 1 & STRA & 84.071665 & bc & $B$ \\
\hline 10 & MESO & 83.996663 & bc & $\mathrm{B}$ \\
\hline 7 & PHA & 81.800ْீ́6 & C & $\mathrm{B}$ \\
\hline
\end{tabular}

Médias seguidas por letras distintas diferem entre si ao nível de significância indicado:
D.M.S. $5 \%=$
4.690840
- D.M.S. $1 \%=$
5.50659 
Quadro n॰11 - Análise de variância para os dados obtidos do ganho de peso.

\begin{tabular}{lccccc} 
C.V. & G.L. & S.Q. & Q.M. & VALOR F & PaOB.>F \\
\hline TRATAMEN & 10 & 9451.1201285 & 945.1120129 & 11.30062 & 0.00001 \\
RESI DLD & 55 & 4597.5781243 & 83.5923295 & & \\
\hline TOTAL & 65 & 14048.6982528 & & & \\
\hline
\end{tabular}

MEDIA GERAL" $=\quad 40.627121$

COEFICIENTE DE VARIAÇ.ÃO = $22.504 \%$

Guadro n॰12 - Resultados da aplicação do teste de Tukey para as médias de tratamentos da variável ganho de peso.

\begin{tabular}{|c|c|c|c|c|}
\hline NUM. TRAT. & NOME & MËDIAS & $5 \%$ & $1 \%$ \\
\hline 11 & CASE & 74.755000 & $a$ & $A$ \\
\hline 6 & PHD & 50.068334 & $b$ & $\mathrm{~B}$ \\
\hline 1 & STRA & 41.846667 & bc & B \\
\hline 7 & $\mathrm{PH} 4$ & 40.288333 & $b c$ & B \\
\hline 4 & T3OM & 37.269999 & bc & $\mathrm{B}$ \\
\hline 8 & PHS & 36.381666 & bc & B \\
\hline 3 & T2OM & 35.803335 & bc & $\mathrm{B}$ \\
\hline 2 & T1OM & 34.623332 & bc & $\mathrm{B}$ \\
\hline 9 & BICA & 33.716667 & be & $\mathrm{B}$ \\
\hline 5 & T4OM & 31.701665 & c & $\mathrm{B}$ \\
\hline 10 & MESO & 30.443334 & c & $\mathrm{B}$ \\
\hline
\end{tabular}

Médias seguidas por letras distintas diferem entre si ao nível de significância indicado:
D.M.S. $5 \%=$
17.733902
D.M.S. $1 \%=$
20.79040 


\section{ANALISE ESTATISTICA DO $\underline{2}^{\circ}$ ENSAIO BIOLOGICO}

Quadro n०13 - Análise de variância para os dados obtidos do ganto de peso.

\begin{tabular}{|c|c|c|c|c|c|}
\hline C.V. & G.L. & S.Q. & Q.M. & VALOR F & $\mathrm{PaOB} .>\mathrm{F}$ \\
\hline $\begin{array}{l}\text { TRATAMEN } \\
\text { RESI DUD }\end{array}$ & $\begin{array}{l}08 \\
45\end{array}$ & $\begin{array}{r}36909.2734262 \\
3210.7430215\end{array}$ & $\begin{array}{r}4613.6591783 \\
71.3498449\end{array}$ & 64.6625 & 0.00001 \\
\hline TOTAL & 53 & 40120.0164478 & & & \\
\hline
\end{tabular}

MEDIA GERAL $=42.592594$

COEFICIENTE DE VARIAÇÃO = $19.832 \%$

Quadro n०14 - Resultados da aplicação do teste de Tukey para as média de tratamento da variável ganho de peso.

\begin{tabular}{|c|c|c|c|c|}
\hline NUM. TRAT. & NOME & MÉdIAS & $5 \%$ & $1 \%$ \\
\hline 9 & CASE & 93.616669 & $a$ & $A$ \\
\hline 2 & PTTCC & 64.633331 & $b$ & $\mathrm{~B}$ \\
\hline 3 & PTSA & 61.433334 & $b$ & B \\
\hline 1 & PTTC & 55.100001 & b & $\mathrm{B}$ \\
\hline 5 & PTSAC & 35.189999 & c & C \\
\hline 4 & PTAC & 23.833533 & cd & $\mathrm{CD}$ \\
\hline 8 & MTAE & 23.649989 & cd & $\mathrm{CD}$ \\
\hline 6 & MTTM & 16.550001 & $d$ & $\mathrm{CD}$ \\
\hline 7 & MIET & 09.316667 & $d$ & $\mathrm{D}$ \\
\hline
\end{tabular}

Médias seguidas por letras distintas diferem entre si ao nível de significåncia indicado:
D.M.S. $5 \%=$
15.92311
$-$
D.M.S. $1 \%=$
18.84565 
Quadro n०15 - Análise de variåncia para os dados obtidos do CEA.

\begin{tabular}{lccccc}
\hline C.V. & G.L. & S.Q. & Q.M. & VALOR F & PaOB.>F \\
\hline TRATAMEN & OB & 0.1507703 & 0.0188463 & 32.8713 & 0.00001 \\
RESI DUD & 45 & 0.0258001 & 0.0005733 & & \\
\hline TOTAL & 53 & 0.1765704 & & & \\
\hline
\end{tabular}

MEDIA GERAL $=\quad 0.170741$

COEFICIENTE DE VARIAÇ.AO $=14.024 \%$

Quadro n॰16 - Resultados da aplicação do teste de Tukey para as médias de tratamento da variável CEA.

\begin{tabular}{lllll}
\hline NUM.TRAT. & NOME & MEDIAS & $5 \%$ & $1 \%$ \\
\hline 9 & CASE & 0.270000 & a & A \\
3 & PTSA & 0.218353 & $b$ & AB \\
2 & PTTCC & 0.201667 & bC & BC \\
1 & PTTC & 0.180000 & bC & BCD \\
8 & MTAE & 0.168333 & cd & BCDE \\
5 & PTSAC & 0.163353 & cde & CDE \\
6 & MTTM & 0.133333 & de & DEF \\
4 & PTAC & 0.120000 & ef & EF \\
7 & MTET & 0.812667 & $f$ & $\mathrm{~F}$ \\
& & & & \\
\hline
\end{tabular}

Médias seguidas por letras distintas diferem entre si ao nível de significância indicado:
D.M.S. $5 \%=$
0.04514
$-$
D.M.S. $1 \%=$
0.053342 
Quadro n॰17 - Análise de variåncia para os dados obtidos do PER.

\begin{tabular}{|c|c|c|c|c|c|}
\hline C.V. & G.L. & S.Q. & Q.M. & VALOR F & $\mathrm{PaOB} .>F$ \\
\hline $\begin{array}{l}\text { TRATAMEN } \\
\text { RESI DLO }\end{array}$ & $\begin{array}{l}08 \\
45\end{array}$ & $\begin{array}{r}14.0744622 \\
2.6689382\end{array}$ & $\begin{array}{l}1.7593078 \\
0.0593097\end{array}$ & 29.6631 & 0.00001 \\
\hline TOTAL & 53 & 16.7434003 & & & \\
\hline
\end{tabular}

MEDIA GERAL = $\quad 1.723333$

COEFICIENTE DE VARIAÇÃO $=14.132 \%$

Quadro n*18 - Resultados da aplicação do teste de Tukey para as médias de tratamento da variável PER.

\begin{tabular}{|c|c|c|c|c|}
\hline NUM. TRAT. & NOME & MEDIAS & $5 \%$ & $1 \%$ \\
\hline 9 & CASE & 2.723353 & $a$ & $A$ \\
\hline 3 & PTSA & 2.170000 & $b$ & B \\
\hline 2 & PTTCC & 2.046667 & be & $\mathrm{BC}$ \\
\hline 1 & PTTC & 1.798353 & be & $\mathrm{BCD}$ \\
\hline 8 & MTAE & 1.695000 & cd & $\mathrm{BCDE}$ \\
\hline 5 & PTSAC & 1.591667 & cde & $\mathrm{CDE}$ \\
\hline 6 & MTTM & 1.335000 & def & DEF \\
\hline 4 & PTAC & 1.190000 & ef & $E F$ \\
\hline 7 & MTET & 0.960000 & $f$ & $F$ \\
\hline
\end{tabular}

Médias seguidas por letras distintas diferem entre si ao nível de significância indicado:
D.M.S. $5 \%=$
0.45909
$-$
D.M.S. $1 \%=$
0.54335 
Quadro $n \bullet 19$ - Análise de variåncia para os dados obtidos NPU.

\begin{tabular}{|c|c|c|c|c|c|}
\hline C.V. & G.L. & S.Q. & Q.M. & VALOR F & PaOB. >F \\
\hline $\begin{array}{l}\text { TRATAMEN } \\
\text { RESI DUO }\end{array}$ & $\begin{array}{l}08 \\
45\end{array}$ & $\begin{array}{l}5458.2414440 \\
1487.6500805\end{array}$ & $\begin{array}{r}682.2801805 \\
33.0588907\end{array}$ & 20.6383 & 0.00001 \\
\hline TOTAL & 53 & 6945.8915245 & & & \\
\hline
\end{tabular}

MEDIA GERAL $=\quad 44.266111$

COEFICIENTE DE VARIAÇ.̃̃O $=12.827 \%$

TESTE DE TUKEY PARA MEDIAS DE TRATAMENTO

Quadro n•20 - Resultados da aplicação do teste de Tukey para as médias de tratamento da variável NPU.

\begin{tabular}{cllcc}
\hline NUM. TRAT. & NCME & MEDIAS & $5 \%$ & $1 \%$ \\
\hline 9 & CASE & 69.231659 & $\mathrm{a}$ & $\mathrm{A}$ \\
8 & MTAE & 48.588328 & $\mathrm{~b}$ & $\mathrm{~B}$ \\
3 & PTSA & 47.161667 & $\mathrm{~b}$ & $\mathrm{~B}$ \\
2 & PTTCC & 46.511668 & $\mathrm{~b}$ & $\mathrm{~B}$ \\
6 & MTIM & 41.326665 & $\mathrm{~b}$ & $\mathrm{BC}$ \\
5 & PTSAC & 41.118332 & $\mathrm{bC}$ & $\mathrm{BC}$ \\
4 & PTAC & 40.440002 & $\mathrm{bC}$ & $\mathrm{BC}$ \\
1 & PTTC & 38.670001 & bC & BC \\
7 & MTET & 30.386668 & $\mathrm{C}$ & $\mathrm{C}$ \\
\hline
\end{tabular}

Médias seguidas por letras distintas diferem entre si ao nível de significancia indicado:
D.M.S. $5 \%=$
10.83866
$-$
D.M.S. $1 \%=$
12.82799 
Quadro n॰21 - Análise de variância para os dados obtidos da D.

\begin{tabular}{|c|c|c|c|c|c|}
\hline C.V. & G.L. & S.Q. & Q.M. & VALOR F & $\mathrm{PaOB} .>F$ \\
\hline $\begin{array}{l}\text { TRATAMEN } \\
\text { RESI DUD }\end{array}$ & $\begin{array}{l}08 \\
45\end{array}$ & $\begin{array}{r}1097.2210613 \\
306.2875497\end{array}$ & $\begin{array}{r}137.1526327 \\
6.8063900\end{array}$ & 20.1506 & 0.00001 \\
\hline TOTAL & 53 & 1403.5086110 & & & \\
\hline
\end{tabular}

MEDIA GERAL $=\quad 82.505371$

COEFICIENTE DE VARIAÇÃO $=3.162 \%$

TESTE DE TUKEY PARA MEDIAS DE TRATAMENTO

Quadro $n \circ 22$ - Resultados da aplicação do teste de Tukey para as médias de tratamento da variável NPU.

\begin{tabular}{ccccc}
\hline NLM.TRAT. & NOME & MEDIAS & $5 \%$ & $1 \%$ \\
\hline & & & & \\
9 & CASE & 69.231659 & $\mathrm{a}$ & $\mathrm{A}$ \\
8 & MTAE & 48.588328 & $\mathrm{~b}$ & $\mathrm{~B}$ \\
3 & PTSA & 47.161667 & $\mathrm{~b}$ & $\mathrm{~B}$ \\
2 & PTTCC & 46.511668 & $\mathrm{~b}$ & $\mathrm{~B}$ \\
6 & MTTM & 41.326665 & $\mathrm{~b}$ & $\mathrm{BC}$ \\
5 & PTSAC & 41.118332 & $\mathrm{bC}$ & $\mathrm{BC}$ \\
4 & PTAC & 40.440002 & bC & $\mathrm{BC}$ \\
1 & PTTC & 38.670001 & bC & $\mathrm{BC}$ \\
7 & MIET & 30.386668 & $\mathrm{C}$ & $\mathrm{C}$ \\
\hline
\end{tabular}

Médias seguidas por letras distintas diferem entre si ao ní vel de significância indicado:

D.M.S. $5 \%=10.83866-$ D.M.S. $1 \%=12.82799$ 
Quadro n॰23 - Análise de variancia para os dados obtidos do V.B.

\begin{tabular}{lccrrr}
\hline C.V. & G.L. & S.Q. & Q.M. & VALOR F & PaCB.>F \\
\hline TRATAMEN & OB & 4450.0462854 & 556.2557857 & 13.8161 & 0.00001 \\
RESI DUO & 45 & 1811.7661871 & 40.2614708 & & \\
\hline TOTAL & 53 & 6261.8124724 & & & \\
\hline
\end{tabular}

MEDIA GERAL = 53.834446

COEFICIENTE DE VARIAÇ.T̃O $=11,786 \%$

TESTE DE TUKEY PARA MEDIAS DE TRATAMENTO

Guadro n०24 - Resultados da aplicação do teste de Tukey para as médias de tratamento da variável do V.B.

\begin{tabular}{cllrl}
\hline NLM. TRAT. & NOME & MEDIAS & $5 \%$ & $1 \%$ \\
\hline & & & & \\
9 & CASE & 74.755000 & $\mathrm{a}$ & $\mathrm{A}$ \\
8 & MTAE & 58.385000 & $\mathrm{~b}$ & $\mathrm{~B}$ \\
2 & PTTCC & 55.981664 & bC & B \\
3 & PTSA & 55.865000 & bC & B \\
4 & PTAC & 51.966670 & bCd & BC \\
5 & PTSAC & 51.598333 & bCd & BC \\
6 & MTTM & 49.953534 & bCd & BC \\
1 & PTTC & 45.861664 & cd & BC \\
7 & MTET & 40.143333 & d & C \\
\hline
\end{tabular}

Médias seguidas por letras distintas diferem entre si ao nível de significancia indicado:
D.M.S. $5 \%=$
11.96124
$-$
D.M.S. $1 \%=$
14.15661 